\title{
Precise developmental regulation of Ets family transcription factors during specification and commitment to the $T$ cell lineage
}

\author{
Michele K. Anderson ${ }^{1,2}$, Gabriela Hernandez-Hoyos ${ }^{1,2}$, Rochelle A. Diamond² and Ellen V. Rothenberg ${ }^{2, *}$ \\ ${ }^{1}$ Stowers Institute for Medical Research, 4949 Rockhill Road, Kansas City, MO 64110, USA \\ 2Division of Biology 156-29, California Institute of Technology, Pasadena, CA 91125, USA \\ *Author for correspondence (e-mail: evroth@its.caltech.edu)
}

Accepted 27 April; published on WWW 21 June 1999

\section{SUMMARY}

Ets family transcription factors control the expression of a large number of genes in hematopoietic cells. Here we show strikingly precise differential expression of a subset of these genes marking critical, early stages of mouse lymphocyte cell-type specification. Initially, the Ets family member factor Erg was identified during an arrayed cDNA library screen for genes encoding transcription factors expressed specifically during $T$ cell lineage commitment. Multiparameter fluorescence-activated cell sorting for over a dozen cell surface markers was used to isolate 18 distinct primary-cell populations representing discrete $T$ cell and B cell developmental stages, pluripotent lymphoid precursors, immature NK-like cells and myeloid hematopoietic cells. These populations were monitored for mRNA expression of the Erg, Ets-1, Ets-2, Fli-1, Tel, Elf-1, GABP $\alpha$, PU.1 and Spi-B genes. The earliest stages in T cell differentiation show particularly dynamic Ets family gene regulation, with sharp transitions in expression correlating with specification and commitment events. Ets, Spi-B and PU.1 are expressed in these stages but not by later T-lineage cells. Erg is induced during T-lineage specification and then silenced permanently, after commitment, at the $\beta$-selection checkpoint. Spi-B is transiently upregulated during commitment and then silenced at the same stage as Erg. T-lineage commitment itself is marked by repression of PU.1, a factor that regulates B-cell and myeloid genes. These results show that the set of Ets factors mobilized during T-lineage specification and commitment is different from the set that maintains $\mathbf{T}$ cell gene expression during thymocyte repertoire selection and in all classes of mature $T$ cells.

Key words: T cell development, Ets family, Gene expression, Hematopoiesis

\section{INTRODUCTION}

$\mathrm{T}$ cells and $\mathrm{B}$ cells constitute the primary recognition and response cells of the vertebrate adaptive immune system. These cells, like all other vertebrate blood cells, develop from hematopoietic stem cells. The branching pathways of lymphocyte development (Fig. 1) involve multiple cell fate determination steps, which include the loss of developmental potential for certain lineages as well as commitment to specific lineages including T cells, B cells and natural killer (NK) cells. There are several unique advantages to using lymphocyte development as a model for cell fate determination. Many successive stages of $\mathrm{T}$ cell and $\mathrm{B}$ cell development can be precisely identified and isolated on the basis of their expression of unique combinations of cell surface markers, allowing very fine scale analysis of gene expression patterns at each stage. Furthermore, because the developmental programs for these cells include the progressive rearrangement of gene segments encoding the B cell or T cell receptors for antigen (Ig and TCR, respectively), the order of the later stages can be established unequivocally by reference to these irreversible DNA alterations. Finally, cell transfer and in vitro differentiation experiments using lymphocyte precursor populations have provided detailed evidence for the developmental potential of each stage. These studies have identified common lymphoid progenitors (CLP) in the bone marrow (Kondo et al., 1997) and among the most primitive cells in the thymus (Wu et al., 1996; Carlyle et al., 1997). In the thymus, such multipotent progenitors undergo a stepwise narrowing of developmental potential, first apparently losing the ability to become B cells, then the potential to become NK cells, and finally the potential to become thymic dendritic cells (DC), thus resulting in commitment to the $\mathrm{T}$ lineage (reviewed in Shortman and Wu, 1996; Zúniga-Pflücker and Lenardo, 1996). We have exploited the ability to isolate cells that are at known stages in the course of this segregation of developmental potentials (Fig. 1) to identify transcription factors that may be involved in cell fate determination in this system.

In spite of the detailed studies available on developmental potential and differentiation stages of lymphocyte maturation, the molecular mechanisms of commitment to the $\mathrm{T}$ and $\mathrm{B}$ cell 
lineages remain elusive. Our studies are designed to address the following questions. (1) Which transcription factors are involved in the loss of alternative developmental potentials and/or positive specification to the lymphoid lineages? (2) How do these factors differ between $\mathrm{B}$ and $\mathrm{T}$ cell developmental lineages, which employ parallel but distinct molecular differentiation events? To some extent we can deduce the gene families to which the critical transcription factors belong by examining the cis-regulatory sequences of lineage-specific genes. However, factors implicated in lymphoid gene expression are often members of multigene families composed of highly related members; although many of these have similar DNA binding specificities, they may differ in their interactions with other factors and with cellular signaling pathways that affect their transcriptional activity. Therefore, analysis of the specific family members that are present at each developmental stage is needed to provide a framework for designing experiments to determine the molecular mechanisms of lymphocyte fate determination.

In these studies we present evidence that nine different transcription factors of the Ets family are expressed in early thymic precursors, and that the majority of these are under lineage- and developmental stage-specific regulation. The Ets family has ancient metazoan origins (Degnan et al., 1993) and its members play critical roles in the development of many different organisms (Lai et al., 1997; Morimoto et al., 1996; Wei et al., 1995; Tan et al., 1998). Here we find that subsets of Ets factors are silenced as lymphoid development progresses, while other subsets are maintained or upregulated in lineage-specific combinations. PU.1, which is essential for development of B cells and macrophages (Scott et al., 1994; McKercher et al., 1996), is expressed in the earliest lymphoid precursors and silenced when they undergo commitment to the T lineage. Erg, a factor that had not been associated with $\mathrm{T}$ cell development previously, is sharply induced at the time of T-lineage specification and shut off once T-lineage commitment is complete. The complexity of the pattern of Ets family expression is unexpected, since both $\mathrm{T}$ and $\mathrm{B}$ cells express many cell-type specific genes throughout their development that have simply been regarded as regulatory targets of the common Ets factor, Ets-1. Our data raise the possibility that other Ets family factors with distinctive biochemical properties may in fact control the regulation of Ets target genes at certain stages of lymphoid development.

\section{MATERIALS AND METHODS}

\section{Animals}

The animals used in this study were C57BL/6 (B6) mice, (B6,129)Rag- $2^{-/-}$mice, C.B-17 SCID mice, B6- $\beta_{2} \mathrm{~m}^{-/-} \mathrm{I}-\mathrm{A} \beta^{-/-}\left(\mathrm{B} 6 \mathrm{MHC}^{-/-}\right)$ mice and B6 SCID mice. Thymus samples were taken from animals 3-5 weeks old, while splenic and bone marrow samples were taken from animals older than 10 weeks. Most of the animals used were bred and maintained under sterile conditions at Caltech. For large experiments, C.B-17 SCID and B6.SJL-ptprc ${ }^{a}-$ Rag- $^{-/-}$mice were obtained from Taconic (Germantown, NY).

\section{RNA extraction and first strand cDNA synthesis}

RNA was extracted using the RNAzol B reagent (Leedo Medical Inc., Houston, TX), according to manufacturer's directions. Poly(A)+ RNA was isolated using Dynal Oligo-T magnetic beads (Dynal, Inc., Oslo, Norway). Sorted cell samples of 20,000-600,000 cells were lysed in 0.5 $\mathrm{ml}$ RNAzol B, and treated as above, adding $20 \mu \mathrm{g}$ of glycogen during the isopropanol precipitation step. After heat-denaturation, the RNA was treated with RNase-free DNase to remove residual genomic DNA. First strand cDNA was generated from total RNA using Superscript RT II (Gibco/BRL, Gaithersburg, MD) and random hexamers (250 ng) according to manufacturer's directions. After first strand synthesis, the cDNA was treated with RNase $\mathrm{H}$ for 30 minutes at $37^{\circ} \mathrm{C}$.

\section{Degenerate PCR}

PCR primers were designed to complement regions of conserved amino acids in the DNA binding domains of different transcription factor family members as follows:

5'ETS-WQFL: CAGTCGACTGGCA(A/G)TT(T/C)(T/C)T 3'ETS-MNDYK:

CAGCGGCCGCTT(A/G)TC(A/G)TA(G/A)TTCAT

3'ETS-MTDYK: CAGCGGCCGCTT(A/G)TC(A/G)TANGTCAT

5'BHLH-ANNA: CCAAGCTTAGCNAA(T/C)AA(T/C)GC

5'BHLH-DINEA:

CCAAGCTTCGA(T/C)AT(T/C/A)AA(T/C)GA(A/G)GC

3’BHLH-NPKA: CCTCTAGAGC(T/C)TTNGG(A/G)TT

5'GATA-CVNC: CAGCGGCCGCTG(T/C)GTNAA(T/C)TG

5'GATA-TGHY: CAGCGGCCGCACNGGNCA(T/C)TA

3'GATA-NACG: CAGTCGACCC(A/C)CANGC(A/G)TT

5'HOX-YPWM: CAGTCGACTA(T/C)CCNTGGATG

3'HOX-WFQN: CAGCGGCCGCTT(T/C)TG(A/G)AACCA

5'PAX-PCDI: CAGCGGCCGCCCNTG(T/C)GA(T/C)AT

3'PAX-WEIR: CAGCGGCCGC(G/T)(A/G)AT(T/C)TCCCA

5'POU-EQFA: CAGCGGCCGCGA(A/G)CA(A/G)TT(T/C)GC

3'POU-NMCK: CAGTCGACTT(A/G)CACAT(A/G)TT

PCR reactions were conducted in $50 \mu \mathrm{l}$ total volume reactions, consisting of 5\% of a first strand C.B-17 SCID thymocyte cDNA reaction, $1 \times$ PCR Buffer II (10 mM Tris $\mathrm{pH} 8.3,50 \mathrm{mM} \mathrm{KCl}), 2 \mathrm{mM}$ $\mathrm{MgCl}_{2}, 0.2 \mathrm{mM}$ dNTPs, $250 \mathrm{ng}$ of each degenerate primer and 2.5 units of AmplitaqGOLD (Applied Biosystems, Foster City, CA). The AmplitaqGOLD was activated by an initial 8 minute incubation at $95^{\circ} \mathrm{C}$, followed by 35 cycles: $95^{\circ} \mathrm{C}$ for 1 minute, $45^{\circ} \mathrm{C}$ for 1 minute, $72^{\circ} \mathrm{C}$ for 1 minute. PCR products were resolved on $4 \%$ agarose gels. Bands of the appropriate sizes were cored, diluted in $1 \times$ TE $(10 \mathrm{mM}$ Tris $\mathrm{pH}$ 8.0, $1 \mathrm{mM}$ EDTA) and reamplified using the same primers, for 25 cycles with a $55^{\circ} \mathrm{C}$ annealing step. Reamplified products were subcloned into the plasmid vector pSPORT1. Individual clones were picked and DNA was extracted using Qiagen spin miniprep kits (Qiagen, Chatsworth, CA). The DNA samples were sequenced, analyzed and used as probes to iteratively screen other recombinants to find multiple family members from the same bands.

\section{cDNA library screening}

A C.B-17 SCID thymocyte random-primed cDNA library was constructed in the pSPORT1 vector (Gibco/BRL), and was arrayed and spotted at high density onto Hybond- $\mathrm{N}^{+}$nylon filters (Amersham, Little Chalfont, Buckinghamshire, UK) using the Q-Bot robot (Genetix, Christchurch, Dorset, UK). Radiolabeled DNA probes were produced by standard random-prime labeling methods using $[\alpha-$ $\left.{ }^{32} \mathrm{P}\right] \mathrm{dCTP}$. The library filters were prehybridized for 1-2 hours in hybridization buffer $\left(5 \times \operatorname{SSPE}\left(0.75 \mathrm{M} \mathrm{NaCl}, 50 \mathrm{mM} \mathrm{NaH} \mathrm{PO}_{4}\right.\right.$, $5 \mathrm{mM}$ EDTA, pH 7.4)/5× Denhardts/0.5\%SDS $/ 0.05 \% \mathrm{Na}_{4} \mathrm{P}_{7} \mathrm{O}_{2}$ ) containing $5 \mathrm{mg}$ heat-denatured sheared salmon sperm DNA. Hybridizations were at $65^{\circ} \mathrm{C}$ for $16-24$ hours, followed by $52^{\circ} \mathrm{C}$ washes with $2 \times \mathrm{SSPE} / 0.1 \% \mathrm{SDS} / 0.05 \% \mathrm{Na}_{4} \mathrm{P}_{7} \mathrm{O}_{2}$ for low stringency screening.

\section{Differential screening of subarray}

DNA samples (100 ng) extracted from cDNA plasmid clones were denatured in $0.4 \mathrm{M} \mathrm{NaOH} / 10 \mathrm{mM}$ EDTA, $\mathrm{pH} 8.2$, heated to $95^{\circ} \mathrm{C}$ for 10 minutes and spotted onto Hybond- $\mathrm{N}^{+}$nylon membranes using a 
Dot Blot Manifold apparatus (Schleicher and Schuell, Keene, NH). The samples were applied to the membranes under vacuum, followed by $500 \mu \mathrm{l}$ of $0.4 \mathrm{M} \mathrm{NaOH}$ per well. Membranes were rinsed with $2 \times$ SSC and air dried. To generate tissue-specific probes, $1 \mu \mathrm{g}$ of poly $(\mathrm{A})^{+}$ RNA from C.B-17 SCID thymocytes, B6 spleen or B6 liver was reverse-transcribed using Superscript RT II and random hexamers, in the presence of $250 \mu \mathrm{Ci}\left[\alpha-{ }^{32} \mathrm{P}\right] \mathrm{dCTP}$. This procedure generated an average of $350 \mathrm{ng}$ of cDNA probe labeled to a specific activity of $3 \times 10^{8} \mathrm{cpm} / \mathrm{ml}$, in a total volume of $100 \mu \mathrm{l}$. Probes were hybridized with the filters as above, for $40-48$ hours at $65^{\circ} \mathrm{C}$, and washed under high stringency conditions at $65^{\circ} \mathrm{C}$ with $0.1 \times \mathrm{SSPE} / 0.1 \% \mathrm{SDS} /$ $0.05 \% \mathrm{Na}_{4} \mathrm{P}_{7} \mathrm{O}_{2}$.

\section{Cell sorting}

Splenocytes, thymocytes, or bone marrow cells were obtained from animals immediately after killing. Cells were incubated in CBSS (5.4 $\mathrm{mM} \mathrm{KCl}, 0.3 \mathrm{mM} \mathrm{Na}_{2} \mathrm{HPO}_{4}, 0.4 \mathrm{mM} \mathrm{KH} \mathrm{PO}_{4}, 4.2 \mathrm{mM} \mathrm{NaHCO} 3$, $137 \mathrm{mM} \mathrm{NaCl}, 5.6 \mathrm{mM}$ D-glucose $\mathrm{pH}$ 7.4)/1\%BSA with clone $2.4 \mathrm{G} 2$ anti-CD32/CD16 (FcyRIII/II) supernatant on ice for 10 minutes, followed by addition of antibodies for staining. Cells stained with biotin-conjugated antibodies were washed with CBSS/1\%BSA before staining with Streptavidin-Red670 (Gibco). Stained cells were sorted using a Coulter Epics Fluorescence-activated cell sorter (Coulter Electronics, Hialeah, FL). All sorted fractions were reanalyzed immediately for purity, and all fractions used here were at least $97 \%$ pure, with the exceptions of populations ' $1 \mathrm{a}$ ' (91\%) and '15' (96\%). Complete data for purity are given in the legend to Table 2 .

All of the antibodies used in this study were obtained from Pharmingen (San Diego, CA) unless otherwise indicated. Rag- $2^{-/}$ thymocytes were stained with Sca-1-biotin, CD44-PE and HSA(CD24)-FITC. Sorting of the CD4 $\left(\mathrm{CD} 4{ }^{+} \mathrm{CD} 8^{-} \mathrm{CD} 3^{+}\right)$and CD8 $\left(\mathrm{CD}^{-} \mathrm{CD}^{+}{ }^{+} \mathrm{CD}^{+}\right)$single positive thymocytes, the $\mathrm{B} 6$ double negative thymocytes $\left(\mathrm{CD}^{-}{ }^{-} \mathrm{CD} 8^{-} \mathrm{CD}^{-}\right)$, and the intermediate single positive thymocytes $\left(\mathrm{CD}^{-} \mathrm{CD}^{+} \mathrm{CD}^{-}\right)$was done in two separate batches after pre-enrichment by depletion of either $\mathrm{CD}^{+}{ }^{+}$or $\mathrm{CD}^{+}$cells using CD4biotin or CD8-biotin with avidin-coupled magnetic beads on a MACS column (Miltenyi Biotec, Auburn, CA). After enrichment, the cells were stained with CD4-PE (Becton-Dickinson, Mountain View, CA), CD8-FITC (Becton-Dickinson) and CD3-670QR (Sigma, St Louis, $\mathrm{MO})$. The double positive thymocytes $\left(\mathrm{CD} 4^{+} \mathrm{CD} 8^{+} \mathrm{TCR} \beta^{\text {lo }}\right)$ were sorted from $\mathrm{B} 6 \mathrm{MHC}^{-/-}$or $\mathrm{B} 6$ mice without pre-enrichment after staining with CD8-FITC, CD4-PE and TCR $\beta-T / C$.

To obtain the fetal $\alpha \beta$ and $\gamma \delta$ T cell subsets, thymuses from B6 E14 mice were cultured as described (Jenkinson and Owen, 1990) for 13 days. The thymuses were stained with TCR $\beta$-PE and TCR $\gamma \delta$-FITC, and sorted as above. For peripheral $\mathrm{T}$ cells, splenocytes were preenriched for $\mathrm{T}$ cells by incubation with B220-biotin and avidinmagnetic beads followed by passage over a MACS column. Preenriched cells were sorted after staining with CD8-FITC, CD4-PE and TCR $\beta$-T/C (Caltag, So. San Francisco, CA). CD $4^{+} \mathrm{CD}^{-}{ }^{-} \mathrm{TCR} \beta^{+}$and $\mathrm{CD} 4^{-} \mathrm{CD} 8^{+} \mathrm{TCR} \beta^{+}$subsets were collected. B220+TCR $\beta^{-}$splenocytes were collected after staining with B220-FITC and TCR $\beta$-T/C, without pre-enrichment.

B6 SCID bone marrow, Rag- $2^{-/-}$bone marrow and B6 bone marrow were used as sources of B cell developmental subsets. The SCID and Rag-2 ${ }^{-/-}$bone marrow cells were stained with CD19-biotin, CD43$\mathrm{PE}$ and B220-FITC. The B6 bone marrow was stained with B220-Cy and IgM-FITC and the $\mathrm{B} 220^{+} \mathrm{IgM}^{-}$and $\mathrm{B} 220^{+} \mathrm{IgM}^{+}$subsets were collected. B6 bone marrow was also stained with Gr-1-FITC and Mac1-FITC, and the FITC $^{+}$fraction was collected as a source of myeloid lineage cells.

\section{Gene-specific PCR}

Primers for gene-specific PCR were designed to discriminate between family members without cross-reactivity. Most primer sets cross exon boundaries. HPRT primers were used to amplify products from serially diluted cDNA samples to achieve normalized samples. PCR parameters for the HPRT reaction ( $25 \mu \mathrm{l}$ total volume) were: 8 minutes $95^{\circ} \mathrm{C}$, followed by $32-35$ cycles at $95^{\circ} \mathrm{C}$ for 45 seconds, $65^{\circ} \mathrm{C}$ for 45 seconds, $72^{\circ} \mathrm{C}$ for 45 seconds in an MJ PTC-200 DNA Engine Thermal Cycler (MJ Research, Inc., Watertown, MA). All primers, listed in Table 1, were used at a final concentration of $0.4 \mu \mathrm{M}$ each. The mb-1 primers (Wang et al., 1998a) were kindly provided by Hua Wang. cDNA samples were normalized according to HPRT levels by dilution in $1 \times$ TE. On average, a 1/50 dilution was made from a 20 $\mu \mathrm{l}$ cDNA sample representing 50,000 sorted cells, and 1-3 $\mu \mathrm{l}$ of the $1 / 50$ dilution were used per PCR reaction, resulting in an average of cDNA from 50-150 cells being amplified per reaction. Primers specific for divergent regions of Ets family members or the PIP gene (Table 1) were used to amplify products from normalized diluted cDNA samples. Reactions were as for HPRT, with the exception of a $60^{\circ} \mathrm{C}$ annealing temperature and a range of 32-40 cycles, depending on the primer set.

No major differences in product distribution were observed between different primer sets used to amplify different portions of the Erg, PU.1 or Ets-1 genes (data not shown). The primer sets referred to here as Spi-B1 (I) and Spi-B2 (II) are specific for the two different promoters used by Spi-B (Chen et al., 1998). The multiple bands represent isoforms of Spi-B according to hybridization to Spi-B specific probes, but they do not correspond in size to the splice isoforms previously reported (Ray-Gallet et al., 1996).

\section{RNA gel blots}

Total RNA was electrophoresed on denaturing agarose gels containing $5 \%$ formaldehyde. The gels were blotted onto Hybond- $\mathrm{N}^{+}$membranes by downward alkaline transfer in $50 \mathrm{mM} \mathrm{NaOH}$ as described (Ingelbrecht et al., 1998). Hybridization to random-primed probes was performed as described above.

\section{Sequencing}

Sequencing was performed using the ABI Prism Dye Terminator Cycle Sequencing Ready Reaction Kit (Perkin-Elmer, Foster City, CA). Sequence analysis was performed using the DNASIS software package (Hitachi Software, Inc., San Francisco, CA).

\section{RESULTS}

\section{A strategy for identification of transcription factors involved in lymphocyte lineage determination}

The initial objective of this work was to identify transcription factors that might play important roles in the mechanism of commitment to the $\mathrm{T}$ cell lineage. cDNA clones encoding such factors should be enriched in cDNA libraries made specifically from cells undergoing the commitment process. The thymuses of immune-deficient SCID and Rag- $2^{-/-}$mice contain only the earliest developmental subsets of thymocytes, and are highly enriched for multipotent progenitors and their progeny undergoing divergence into the natural killer (NK), dendritic cell (DC) and T cell lineages. As many as $15-20 \%$ of the cells at steady state in the SCID thymus, for example, appear not to have undergone complete commitment to the T cell lineage yet (Diamond et al., 1997; Shortman and Wu, 1996; Wu et al., 1996). The thymus populations of these mutant mice thus offer access to the molecular biology of several steps of lymphocyte developmental choice (see Fig. 1).

A three-step strategy was designed to identify cDNA clones from SCID thymocytes that encode transcription factors expressed at the right time to serve developmental roles. First, 
a degenerate-primer RT-PCR approach was used to amplify sequences expressed in SCID thymocyte RNA that encode conserved transcription factor domain motifs. The sequences of these amplified products provided one source of expression data. Second, a cDNA library was constructed from SCID thymocyte poly(A) ${ }^{+}$RNA, and robotically arrayed for archiving and high-density filter screening. Mixtures of unique, ampified sequences generated by degenerate-primer RT-PCR were used as probes to identify putative transcription factor clones in the library. Finally, clones from the cDNA library that

Fig. 1. Developmental potential and progression of lymphoid progenitors. This figure shows the developmental progression of the cell types sorted and analyzed for Ets factor expression at the mRNA level in this study. The numbering and color scheme used in this figure are consistent throughout this paper. Populations which occur in the thymus, bone marrow $(\mathrm{BM})$ or spleen are designated in the upper lefthand oval, the lower lefthand oval, or the righthand oval, respectively, as indicated by the italicized labels. Hematopoietic stem cells (HSC) and BM-derived common lymphoid progenitors (CLP) were not collected but are included in this figure to show their developmental relationships with the other populations. Detailed phenotypes of all of the populations analyzed in this study are listed in Table 2. White circles indicate multipotent progenitors. Striped circles indicate specification towards specific lineages prior to actual commitment. Specification is defined here as the upregulation of lineage-specific genes, while commitment is defined as the loss of developmental potential to become any other cell type. Solid lines indicate well-

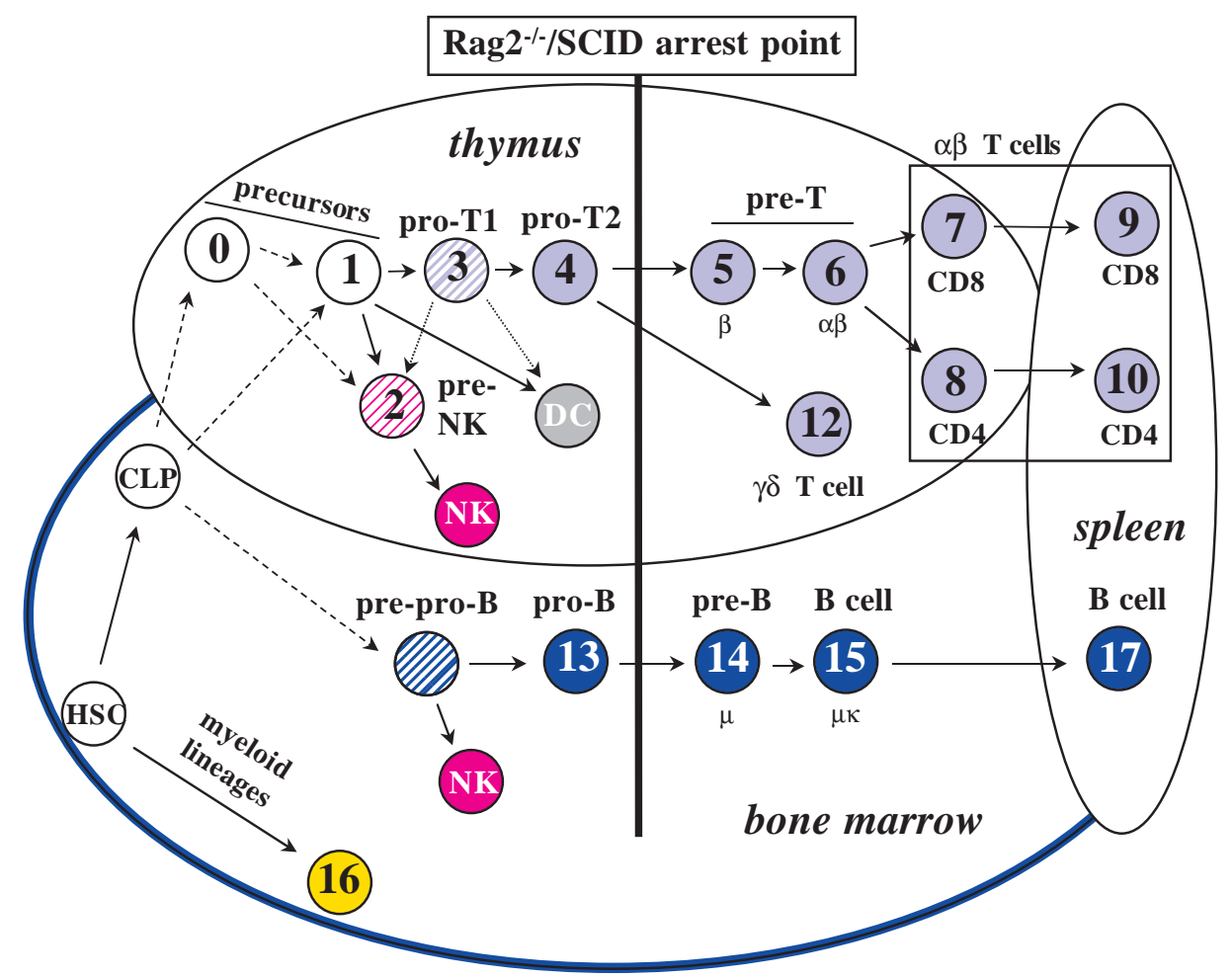

defined differentiation pathways, dashed lines indicate possible differentiation pathways, and dotted lines indicate a low (measured) probability of differentiation along that pathway. Rag- $2^{-1-}$ and SCID mice, which cannot rearrange either the immunoglobulin (Ig) or T cell receptor (TCR) genes, contain only the lymphoid populations to the left of the thick black vertical line, while normal mice contain all of the lymphoid populations depicted here. HSCs can differentiate either towards the lymphoid lineages, resulting in common lymphoid progenitors (CLPs; not included in this study), or towards the erythroid and/or myeloid lineages (population 16=mixed myeloid lineage cells). The CLP retains the potential to develop into any of the classical lymphoid lineages, including T cells, B cells and natural killer (NK) cells, as well as thymic dendritic cells (DC), but not any of the myeloid or erythroid cell types. The CLP or its progeny may differentiate towards the B cell lineage in the bone marrow (pre-pro-B; not collected) or migrate to the thymus (populations 0 and/or 1). The pre-pro-B cells express some B lineagespecific genes such as B220 but are not yet committed, and retain the potential to develop in the bone marrow into NK cells (Rolink et al., 1996). The pro-B cells (population 13) have not yet rearranged their Ig heavy or light chain genes, but are believed to be committed to the B cell lineage (Hunte et al., 1998). Some of these cells also are contained in population 14 (pre-B cells) because of the criteria for selection (see Table 2). The bulk of the cells in population 14, however, are pre-B cells which have rearranged their Ig heavy chains and express cytoplasmic $\mu$ chains but do not yet express the pre-B cell receptor (pre-BCR), composed of the IgM heavy chain and the surrogate light chains $\lambda 5$ and $\mathrm{V}_{\text {pre }} \mathrm{B}$, on the cell surface. Rearrangement and expression of an Ig light chain locus results in expression of membrane-bound IgH-IgL heterodimers and B cell maturation. Population 15 contains primarily cells which express the mature BCR, and are likely a combination of immature and mature B cells, with a preponderance of the latter. Mature B cells transit to the peripheral organs, including the spleen, where they may undergo class switching; therefore, the splenic B cells collected here (population 17) likely contain a mixture of B cell expressing different isotypes, of which most are IgM-bearing B cells. The progeny of the HSC or CLP that transit to the thymus are probably contained within the thymic progenitor populations represented by populations 0 and 1 . They can either differentiate towards the NK cell lineage (population 2) or the T cell lineage (population 3). Pro-T1 cells retain the ability, although decreased compared with that of the thymic progenitors, to become an NK cell or a thymic DC, while pro-T2 cells (population 4) are committed to the T lineage. Pro-T2 cells either rearrange their TCR $\beta$ chains or their TCR $\gamma$ chains. Successful rearrangement and expression of both TCR $\gamma$ and TCR $\delta$ chains results in the production of $\gamma \delta$ T cells. The majority of these cells are produced in specific waves in the fetal mouse thymus, and population 12 examined here is of fetal origin. However, both $\alpha \beta$ and $\gamma \delta$ T cells are produced in the thymus (with a much higher ratio of $\alpha \beta$ T cells to $\gamma \delta$ T cells) postnatally and throughout the lifetime of the animal. Both fetal and adult $\gamma \delta \mathrm{T}$ cells differentiate from pro-T cells which are already committed to the $\mathrm{T}$ lineage, represented here by the pro-T2 stage (population 4). All subsequent stages of T cell development examined here progress towards the $\alpha \beta$ T cell lineages. Pre-T cells (immature single positive CD ${ }^{+}$cells: ISP; population 5 ) have successfully rearranged the TCR $\beta$ chain and express the pre-TCR composed of TCR $\beta$ and pre-T- $\alpha$. Successful TCR $\alpha$ chain rearrangement and expression results in cell surface expression of the TCR $\alpha \beta$ heterodimer (Double positive $C D 4^{+} \mathrm{CD} 8^{+}$cells: DP; population 6 ). These pre-T cells are subjected to both positive and negative selection before maturing into either $\mathrm{CD}^{+}$(killer) single positive (SP) T cells (population 7) or $\mathrm{CD}^{+}$(helper) SP T cells in the thymus. These cells migrate into the peripheral lymphoid organs including the spleen (populations 9 and 10). 
hybridized with these transcription factor domain probes were subarrayed and screened with total cDNAs from distinct tissues to identify factors of particular developmental interest. This paper reports one striking aspect of the findings that emerged from this program.

\section{Differential expression analysis: Erg and HEB transcripts specifically enriched in early thymocytes}

To achieve the first aim described above, degenerate PCR primers complementing conserved amino acids of the DNA binding domains of the Ets, Class A bHLH, GATA, POU, Hox and Pax families were used to amplify products from SCID thymocyte first strand cDNA. Appropriately sized bands were cloned and multiple clones were sequenced. Clones were iteratively screened to be certain that all different PCR products contained within a band were detected. The Ets PCR primers amplified four known Ets family members: Erg, ERM, Elk-1 and ERP. The Class A bHLH family primers amplified all three known family members (E2A, HEB and E2-2, using the human nomenclature). The GATA primers amplified GATA-3, the POU primers amplified Oct-1 and EMB and the Pax primers amplified Pax-1 and Pax-9. The Hox primers amplified HoxB4. These PCR products were pooled and used to screen the arrayed SCID thymocyte cDNA library (70,000 clones) at low stringency in order to detect all related cDNAs. Clones hybridizing at various intensities were isolated and partially characterized. The Ets family member clones were: Fli-1 (2 clones), ERP ( 2 clones) and Erg (1 clone). Other clones retrieved from the library included GATA-3 (1 clone), E2A (2 clones), Pax-1 (2 clones), HEB ( 2 clones) and Oct-1 ( 2 clones).

Table 1. Gene-specific PCR primers for RT-PCR analysis of sorted developmentally staged lymphocyte populations

\begin{tabular}{|c|c|c|}
\hline Gene & Primers and probe & Product size (bp) \\
\hline \multirow[t]{2}{*}{ HPRT } & S-CCAGCAAGCTTGCAACCTTAACCA & 176 \\
\hline & A-GTAATGATCAGTCAACGGGGGAC & \\
\hline \multirow[t]{2}{*}{ ETS-1 } & S-CTACGGTATCGAGCATGCTCAGTG & 192 \\
\hline & A-AAGGTGTCTGTCTGGAGAGGGTCC & \\
\hline \multirow[t]{2}{*}{ ETS-2 } & S-ACTCTCACCTCAACGCGGTTCCTC & 249 \\
\hline & A-GGAAGTCCTGGCTGATGGAACAGT & \\
\hline \multirow[t]{2}{*}{ FLI-1 } & S-CCAGAACATGGATGGCAAGGA & 303 \\
\hline & A-CCCGGAATCTGATAAGGATCTGGC & \\
\hline \multirow[t]{3}{*}{ ERG } & (I) S-CAGCGGCTCACGCCGAGCTACAAT & 284,214 \\
\hline & (II) S-CAGTATATCCCGAAGCTACGC & 108 \\
\hline & A-TTTGGACTGAGGGGTGAGGTGGCT & \\
\hline \multirow{2}{*}{ PU.1 } & S-ATGGAAGGGTTTTCCCTCACCGCC & 216 \\
\hline & A-GTCCACGCTCTGCAGCTCTGTGAA & \\
\hline SPI-B1 & (I) S-CATGCTTGCTCTGGAGGCTGCACA & 261 \\
\hline SPI-B2 & (II) S-CCTGACATGCCCCTGTGTCTCT & 269 \\
\hline SPI-B* & A-AGCAGGATCGAAGGCTTCATAGGG & \\
\hline \multirow[t]{2}{*}{ ELF-1 } & S-ACAGTGCCACTCACAACGGT & 240 \\
\hline & A-CGCTCCATTGCAAATGGACTG & \\
\hline \multirow[t]{2}{*}{ TEL } & S-ACTCTATCCACACCAAGCCAG & 242 \\
\hline & A-GGCTTTCTCCACTGGCGAGA & \\
\hline \multirow[t]{2}{*}{$\mathrm{GABP} \alpha$} & S-CTTGGCATCCCCTATGATCCT & 258 \\
\hline & A-CATCTGTTGCTCTTGGCTGGC & \\
\hline \multirow[t]{2}{*}{ PIP } & S-TGAGAAGTTGCTGAGCCACCT & 372 \\
\hline & A-GTATCGTGTTCAGGTAACTCG & \\
\hline \multicolumn{3}{|c|}{$\begin{array}{l}\text { A, antisense; } \mathrm{S} \text {, sense. } \\
\text { *Antisense primer used with either sense primer for splice isoform } \\
\text { Implification. }\end{array}$} \\
\hline
\end{tabular}

To analyze the tissue distribution of these clones, plasmid DNA was extracted from each of the clones which had hybridized with the pooled transcription factor probes. These DNA samples were subarrayed in a dot blot format onto three triplicate nylon membranes for differential screening (Fig. 2). Each subarray was hybridized to radiolabeled first strand cDNAs from SCID thymocytes, spleen and liver. The SCID thymocyte cDNA probe was used to generate an immature thymocyte expression profile, and the liver cDNA probe was used to identify and exclude nonlymphoid-specific genes. To identify genes used specifically in early lymphoid lineage divergence events, a spleen cDNA probe was also used to exclude genes expressed at high levels in mature lymphocytes. This type of differential screen allows the comparison of the relative expression levels of a large number of genes at the same time, in that the differences in the intensity of the spots should correspond to the prevalence of those transcripts in each respective tissue type. Spot intensity was compared, and three clones were chosen for further analysis based on more intense hybridization to the SCID thymocyte probe than to the spleen or liver probes (Fig. 2). Sequencing revealed that one of these clones encodes a portion of the Ets family member Erg, and the other two encode portions of the bHLH family member HEB.

The finding that Erg is expressed at higher levels in SCID thymocytes than in the spleen was surprising, in part because Erg has been implicated in B cell but not $\mathrm{T}$ cell gene expression (Rivera et al., 1993), and in part because Ets-1 and Elf-1 are the Ets family members that have been predominantly associated with $\mathrm{T}$ cell development and function in previous studies (Muthusamy et al., 1995; Bories et al., 1995; Ernst et al., 1996). One essential question arising from this finding was whether the cells expressing Erg in the SCID thymus are T cell precursors, nonlymphoid thymic stromal cells, or lymphocytes of another lineage. If indeed Erg is expressed by $\mathrm{T}$ cell precursors, it also raises the important question of when its expression is shut off. Between the SCID arrest point and the arrival of mature $\mathrm{T}$ cells in the periphery lie the most intensely studied events that occur in thymocyte differentiation: the stages when cell fate is determined by $\mathrm{T}$ cell receptor interactions with the environment, and positive and negative selection events shape the antigen-recognition repertoire of the $\mathrm{T}$ cell population as a whole. The second essential question is therefore whether the expression of Erg is extinguished during the early, antigen receptor-independent phase of thymocyte development, or in a later, antigen receptor-dependent transition. In order to confirm the differential expression analysis results and address these questions, RT-PCR was conducted on first strand cDNA samples derived from highly defined, sorted, thymic, splenic and bone marrow cell populations, as described below.

\section{System for analysis of Ets family gene regulation relative to landmarks in lymphocyte development}

Early stages in lymphocyte development cannot be distinguished by spatial and/or temporal coordinates, nor by morphology, so that in situ hybridization methods are inadequate to define developmental gene expression programs. 
However, ample tools are available to trace cells through this process. We used over a dozen cell-surface markers for fluorescence-activated cell sorting and took advantage of targeted mutations that block lymphocyte development at defined points to isolate 18 different cell populations (pops) representing known stages in lymphocyte development. Populations of lymphocyte precursors for which developmental potentials have been determined by cell transfer and in vitro differentiation studies are shown schematically in Fig. 1 and discussed in detail in the legend to Fig. 1 (Rolink et al., 1996; Li et al., 1996; Kondo et al., 1997; Wu et al., 1996; Carlyle et al., 1997; Shortman and Wu, 1996). Although specification and commitment to the $\mathrm{T}$ cell and $\mathrm{B}$ cell lineages are accompanied by the beginning of TCR and Ig gene rearrangement, respectively, it is also possible to distinguish 'pro- $\mathrm{T}$ ' and 'pro-B' cell stages prior to rearrangement when the cells have instituted T- and B-cell specific gene expression programs ( $\mathrm{Li}$ et al., 1993, 1996; Wang et al., 1998a,b). Therefore, the pro-T (pops 3, 4) and pro-B (pop. 13) cells isolated in this study have undergone specification even if they are not yet irreversibly committed to the $\mathrm{T}$ or $\mathrm{B}$ cell lineage. After commitment to the T cell lineage, another developmental choice occurs: the $\alpha \beta$ (pop. 11, fetal) versus the $\gamma \delta$ (pop. 12, fetal) $\mathrm{T}$ cell lineage. Cells which successfully rearrange the TCR $\gamma$ and $\delta$ chain genes follow an alternative route to becoming mature $\gamma \delta \mathrm{T}$ cells, while those expressing the TCR $\beta$ chain encounter the first developmental checkpoint ( $\beta$ selection) along the primary path of $\mathrm{T}$ cell development towards the $\alpha \beta$ T cell lineage. The $\beta$ selection checkpoint is so called because only cells which successfully express the TCR $\beta$-chain in the pre-TCR complex can survive and proliferate thereafter. Cells that cannot carry out rearrangement at all, e.g. in the SCID and Rag- $2^{-/-}$mutants, arrest their development at this point (pop. 0-4).

After $\beta$-selection, thymocytes acquire the CD4 and CD8 markers and go through a transitional intermediate (ISP, pop. 5) to become 'double positive' (DP, pop. 6). After the second checkpoint, when the cells are tested for TCR recognition specificity, they lose either CD4 or CD8 and become 'single positive' (SP, pops 7,8 ). This transition involves yet another developmental choice: the choice to become an SP helper $\left(\mathrm{CD}^{+}\right)$cell (pop. 8) or an SP killer $\left(\mathrm{CD}^{+}\right)$cell (pop. 7). At each checkpoint, cells that fail die and the cells that succeed move to the next stage of maturation. Successful transit through each checkpoint is followed by sharp changes in cellcycle status and functional activity (Rothenberg et al., 1994; Hoffman et al., 1996; Rincon and Flavell, 1996). The cells then leave the thymus to function in the periphery as mature $\mathrm{T}$ cells (including pops 9 and 10). B cells undergo a similar sequence of developmental checkpoints (see Fig. 1), although conventional B cell progenitors may not have choices analogous to the TCR $\alpha \beta / \gamma \delta$ or helper/killer split.

Populations representing the earliest stages of T-cell development have been studied intensively by our laboratory and the laboratories of others. The changes in developmental potential indicated in Fig. 1 have been robustly associated with phenotypic landmarks (reviewed by Shortman and Wu, 1996; Zúñiga-Pflücker and Lenardo, 1996; Rothenberg et al., 1999), and these criteria have been used to define the populations we compare in the present work. Furthermore, our own previous RT-PCR analyses of populations 1-4 (Wang et al., 1998a,b) have shown that these subsets express dramatically distinct, reproducible patterns of $\mathrm{T}$ and non- $\mathrm{T}$ lineage associated genes. Each pattern is characteristic of the cell type regardless of the mouse strain from which it is isolated. Thus, cell sorting and RT-PCR analysis under the conditions used here are sufficiently sensitive and quantitative to define changes in gene regulation that correlate with key transitions in lymphocyte development.

The range of populations analyzed in this study (Table 2) allows us to distinguish potential roles for Erg and other Ets family members in specification to the $\mathrm{T}$ lineage from potential roles in cell cycle control, susceptibility to apoptosis, helper versus killer function, or activation status. To establish the
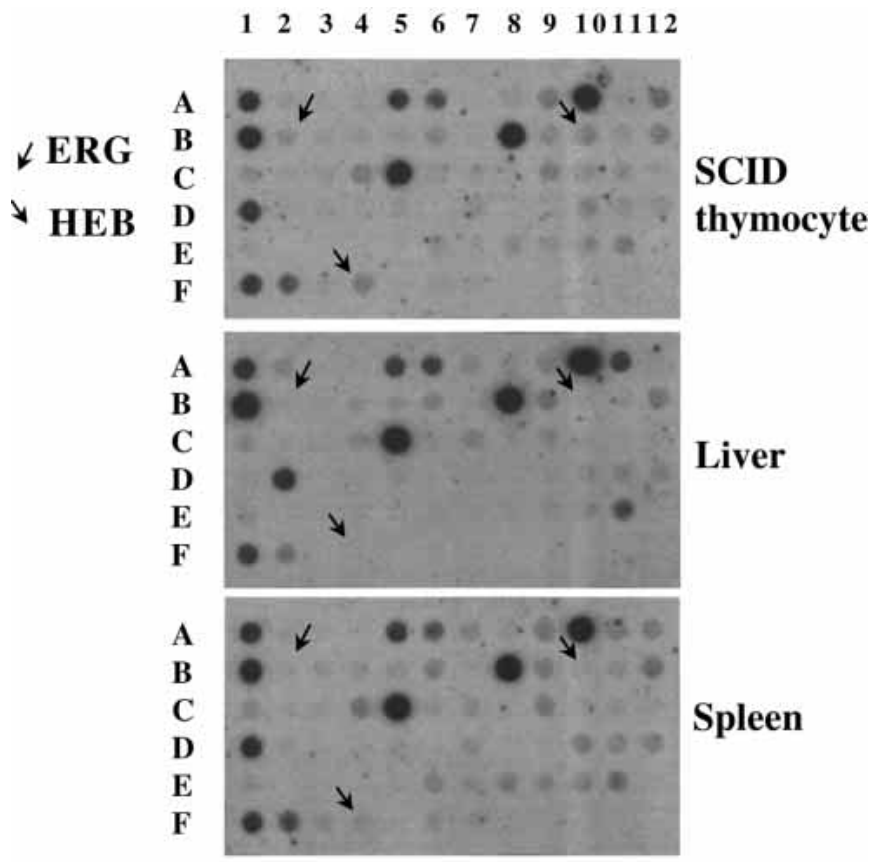

Fig. 2. Differential screening of SCID thymocyte cDNA subarray. DNA extracted from SCID thymocyte cDNA clones, which hybridized at low stringency to a mixed batch of probes for BHLH, ETS, GATA, HOX, PAX and POU transcription factor family members, was arrayed on three identical nylon membranes. The three membranes were probed at high stringency: the top membrane with radiolabeled cDNA from SCID thymocytes, the middle membrane with radiolabeled cDNA from liver, and the bottom membrane with radiolabeled cDNA from spleen. Hybridization intensities are indicative of relative abundance of the message complementing each clone in each tissue. The membranes were exposed to film and phosphorimager screens for varied amounts of time; this figure represents a 3-day exposure to a phosphorimager screen. Several of the clones were sequenced; many of the sequences were not clearly related to any other sequences in GenBank. The clones at the following coordinates were identified by sequence analysis to be: 1A, Wiskott-Aldrich protein; 1C, Pax-1; 2B, Erg (denoted by leftward slanted arrow); 2E, E2A; 3D, GATA-3; 3E, Oct-1; 3F, Erp; 4F, HEB (also known as Alf-1 or ME-1, and denoted by rightward slanted arrow); 5F, Pax-1; 6E, Erp; 6F, E2A; 7A, $\gamma$ catenin; 7D, Fli-1; 8E, Fli-1; 9B, triose phosphate isomerase; 10B, HEB (denoted by rightward slanted arrow). 
Table 2. Descriptions of the cell populations isolated and examined in this study

\begin{tabular}{|c|c|c|c|c|c|}
\hline \multirow[b]{2}{*}{ Population number } & \multirow[b]{2}{*}{ Name } & \multirow[b]{2}{*}{ Tissue } & \multicolumn{2}{|c|}{ Phenotype } & \multirow[b]{2}{*}{ Proposed developmental significance } \\
\hline & & & Sorted $\ddagger$ & Additional & \\
\hline 0 & Precursor & $\begin{array}{l}\text { SCID } \\
\text { thymus }\end{array}$ & $\begin{array}{l}\text { Sca-1- } \\
\text { HSA }^{-} \\
\text {Thy-1- }\end{array}$ & $\begin{array}{l}\mathrm{CD}^{-} 5^{-} \\
\mathrm{CD} 44^{+} \\
\mathrm{c}-\mathrm{kit}^{+} \\
\text {Sca- } 1->+\end{array}$ & $\begin{array}{l}\text { Potentially most enriched source of earliest common lymphoid precursors in } \\
\text { thymus that retain potential for T, B, NK and DC lineages: but not fully } \\
\text { characterized. }\end{array}$ \\
\hline 1 & Precursor & $\begin{array}{l}\text { Rag- } 2^{-/-} \\
\text {thymus }\end{array}$ & $\begin{array}{l}\mathrm{Sca}^{+} 1^{+} \\
\mathrm{HSA}^{-}\end{array}$ & $\begin{array}{l}\mathrm{CD}^{2} 5^{-} \\
\mathrm{CD} 44^{+} \\
\mathrm{c}-\mathrm{kit}^{+} \\
\text {Thy-1+>- }\end{array}$ & $\begin{array}{l}\text { Thymic lymphoid progenitor which is likely to retain potential for T, NK, DC } \\
\text { and maybe B lineages. Unrearranged TCR genes, no Rag-1 expression. }\end{array}$ \\
\hline $1 \mathrm{a}$ & Prexcursor & $\begin{array}{l}\text { Rag- } 2^{-/-} \\
\text {thymus }\end{array}$ & $\begin{array}{l}\text { Sca-1 } 1^{+/ \text {int }} \\
\text { HSA }^{-/ i n t}\end{array}$ & $\begin{array}{l}\mathrm{CD} 25^{-} \\
\mathrm{CD} 44^{+} \\
\mathrm{c}-\mathrm{kit}^{+}\end{array}$ & $\begin{array}{l}\text { Mixture of pop. } 1 \text { precursors and cells in transit to pop. } 3 \text { pro-T cells; gene } \\
\text { expression patterns link these cells more closely to pop. } 3 \text { than pop. } 1 \text {. }\end{array}$ \\
\hline 2 & Pre-NK & $\begin{array}{l}\text { Rag- } 2^{-/-} \\
\text {thymus }\end{array}$ & $\begin{array}{l}\text { Sca-1 }^{-} \\
\mathrm{HSA}^{-}\end{array}$ & $\begin{array}{l}\mathrm{CD}^{4^{+}} \\
\mathrm{c}-\mathrm{kit}^{+} \\
\mathrm{NK} 1.1^{+} \\
\mathrm{CD} 122^{+}\end{array}$ & $\begin{array}{l}\text { Immature NK cell precursors; commitment status unknown. Expressing } \\
\text { perforin, IL- } 2 \text { and IL } 7 R \alpha \text { mRNAs. Includes small percentage of precursors } \\
\text { from pop. } 0 \text { unless selected for Thy-1 expression (see pop. } 2 \mathrm{a} \text { ). }\end{array}$ \\
\hline $2 \mathrm{a}$ & Pre-NK & $\begin{array}{l}\text { SCID } \\
\text { thymus }\end{array}$ & $\begin{array}{l}\text { Sca- } 1^{-} \\
\mathrm{HSA}^{-} \\
\text {Thy-1 }\end{array}$ & $\begin{array}{l}\mathrm{CD}^{\mathrm{c}} 44^{+} \\
\mathrm{c}-\mathrm{kit}^{+} \\
\mathrm{NK} 1.1^{+} \\
\mathrm{CD} 122^{+}\end{array}$ & $\begin{array}{l}\text { Immature NK precursors purified away from other lymphoid precursors; } \\
\text { commitment status unknown. }\end{array}$ \\
\hline 3 & Pro-T1 & $\begin{array}{l}\text { Rag- } 2^{-/-} / \mathrm{SCID} \\
\text { thymus }\end{array}$ & $\begin{array}{l}\text { Sca- } 1^{+} \\
\mathrm{HSA}^{+} \\
\mathrm{CD}^{+} 4^{+}\end{array}$ & $\begin{array}{l}\mathrm{CD}^{2} 5^{+} \\
\mathrm{c}-\mathrm{kit}^{+}\end{array}$ & $\begin{array}{l}\text { Pro-T cells specified but not yet committed to the T lineage; retain reduced } \\
\text { potential for NK and DC lineages. Expressing Rag- } 1, \text { CD } 3-\varepsilon, \text { TdT, pre-T } \alpha \\
\text { mRNAs. Normal pro-T1 cells begin TCR } \beta \text { (or TCR } \gamma \text { ) rearrangement; } \\
\text { Rag-2 } 2^{-/} \text {cells cannot begin rearrangements, SCID cells cannot finish them. } \\
\text { Enriched for proliferating cells. }\end{array}$ \\
\hline 4 & Pro-T2 & $\begin{array}{l}\text { Rag- } 2^{-/-} \\
\text {thymus }\end{array}$ & $\begin{array}{l}\mathrm{Sca}_{-}^{+} \\
\mathrm{HSA}^{+} \\
\mathrm{CD}^{-} 4^{-}\end{array}$ & $\begin{array}{l}\mathrm{CD} 25^{+} \\
\mathrm{c}^{-} \mathrm{kit}^{-}\end{array}$ & $\begin{array}{l}\text { Pro-T cells committed to the T lineage, undergoing TCR } \beta \text { or TCR } \gamma \text { rearrange- } \\
\text { ments normally, noncycling until after } \beta \text { selection, die if rearrangements are } \\
\text { unsuccessful. In Rag- } 2^{-/-} \text {thymus, none can survive past this point. }\end{array}$ \\
\hline 5 & ISP pre-T & thymus & $\begin{array}{l}\mathrm{CD}^{+} \\
\mathrm{CD}^{-} \\
\mathrm{CD}^{-}\end{array}$ & $\begin{array}{l}\mathrm{CD}^{2} 5^{-} \\
\mathrm{TCR} \alpha \beta^{-}\end{array}$ & $\begin{array}{l}\text { Intermediate 'single positive' pre-T cell, has passed } \beta \text { selection, undergoing } \\
\text { proliferative burst, begins to rearrange TCR } \alpha \text { chains. }\end{array}$ \\
\hline 6 & DP pre-T & $\begin{array}{l}\mathrm{MHC}^{-/-} \\
\text {thymus }\end{array}$ & $\begin{array}{c}\mathrm{CD}^{+} \\
\mathrm{CD} 4^{+} \\
\mathrm{TCR} \alpha \beta^{\mathrm{lo}}\end{array}$ & & $\begin{array}{l}\text { Committed pre-T cell, 'double positive' because of CD4 and CD8 expression; } \\
\text { TCR } \beta \text { is rearranged and TCR } \alpha \text { is undergoing rearrangement; this population } \\
\text { normally undergoes negative and positive selection but cannot do either in } \\
\text { genetic background that lacks MHC expression, thus remains homogeneous. }\end{array}$ \\
\hline 7 & CD8-SP & thymus & $\begin{array}{l}\mathrm{CD}^{-} \\
\mathrm{CD}^{+} \\
\mathrm{CD}^{+}\end{array}$ & $\mathrm{TCR} \alpha \beta^{+}$ & $\begin{array}{l}\text { Cells which have passed both positive and negative selection events and } \\
\text { are maturing in the thymic medulla and acquiring a killer phenotype }\end{array}$ \\
\hline 8 & CD4-SP & thymus & $\begin{array}{l}\mathrm{CD}^{+} \\
\mathrm{CD}^{-} \\
\mathrm{CD}^{+}\end{array}$ & $\mathrm{TCR} \alpha \beta^{+}$ & $\begin{array}{l}\text { Cells which have passed both positive and negative selection events and } \\
\text { are maturing in the thymic medulla and acquiring a helper phenotype. }\end{array}$ \\
\hline 9 & Spl CD8 & spleen & $\begin{array}{c}\mathrm{CD}^{+} \\
\mathrm{CD} 4^{-} \\
\mathrm{TCR} \alpha \beta^{+}\end{array}$ & & Mature peripheral killer T cells. \\
\hline 10 & Spl CD4 & spleen & $\begin{array}{c}\mathrm{CD}^{+} \\
\mathrm{CD} 8^{-} \\
\mathrm{TCR} \alpha \beta^{+}\end{array}$ & & Mature peripheral helper T cells. \\
\hline 11 & Fetal $\alpha \beta$ & FTOC & $\begin{array}{l}\operatorname{TCR} \alpha \beta^{+} \\
\operatorname{TCR} \gamma \delta^{-}\end{array}$ & & $\begin{array}{l}\alpha \beta \text { T cells which developed in fetal thymic organ culture from day } 14 \\
\text { fetal thymus lobes. }\end{array}$ \\
\hline 12 & Fetal $\gamma \delta$ & FTOC & $\begin{array}{l}\mathrm{TCR} \gamma \delta^{+} \\
\mathrm{TCR} \alpha \beta^{-}\end{array}$ & & $\begin{array}{l}\alpha \beta \text { T cells which developed in fetal thymic organ culture from day } 14 \\
\text { fetal thymus lobes. }\end{array}$ \\
\hline 13 & pro-B & $\begin{array}{c}\text { SCID } \\
\text { bone marrow }\end{array}$ & $\begin{array}{l}\mathrm{B} 220^{+} \\
\mathrm{CD}^{+} 3^{+} \\
\mathrm{CD} 19^{+}\end{array}$ & $\operatorname{IgM}^{-}$ & Specified or committed B-lineage precursors prior to IgH rearrangement. \\
\hline 14 & pre-B & bone marrow & $\begin{array}{l}\mathrm{B} 220^{+} \\
\mathrm{IgM}^{-}\end{array}$ & & $\begin{array}{l}\text { Mixture of pro-B and pre-B cells prior to } \operatorname{IgH} \text { cell surface expression, } \\
\text { heavily biased towards pre-B cells due to a proliferative burst after } \operatorname{IgH} \\
\text { rearrangement. }\end{array}$ \\
\hline 15 & B cell & bone marrow & $\begin{array}{l}\mathrm{B} 220^{+} \\
\mathrm{IgM}^{+}\end{array}$ & & Mixture of immature and mature B cells expressing $\operatorname{IgM}$ on the surface \\
\hline 16 & Myeloid & bone marrow & $\begin{array}{c}\text { Gr-1+ } \\
\text { Mac-1 }{ }^{+}\end{array}$ & & Mixture of immature and mature granulocytes and macrophages. \\
\hline 17 & Spl B & spleen & $\begin{array}{c}\mathrm{B} 220^{+} \\
\text {TCR } \alpha \beta^{-}\end{array}$ & & Mature peripheral B cells, probably mostly IgM and IgG bearing B cells. \\
\hline
\end{tabular}

*Cells were obtained from mice of different genotypes to maximize purity of the desired population. For a detailed comparison of the properties of immature

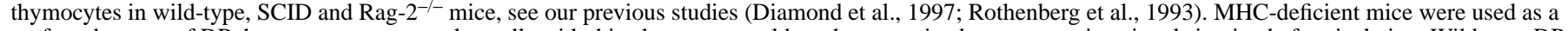

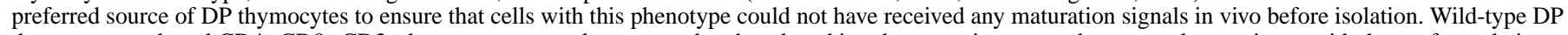
thymocytes and total $\mathrm{CD}^{-} \mathrm{CD}^{-} \mathrm{CD} 3^{-}$thymocytes were also prepared and analyzed in other experiments, and gave results consistent with those of populations from mutant animals (data not shown).

$\ddagger$ Purities of sorted fractions used in this work were determined by reanalysis, as follows. Pop. 0, >97\%; Pop. 1, >98\%; Pop. 1a, $91 \%$ (heterogeneous for Sca-1 expression); pop. 2, 97\%; pop. 2a, 97\%; pop. 3, >98\% (but CD44 heterogeneous, only 90\% CD44high); pop. 4, approx. 100\%; pop. 5, >99\%; pop. 6, approx.

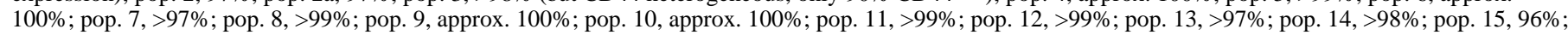
pop. 16 , approx. $100 \%$; pop. 17 , approx. $100 \%$. 
elements of the expression pattern that are T-lineage specific, immature and mature B cell subsets, a putative immature NK population, and mixed mature and immature myeloid cells were also analyzed in parallel. In many cases, we took advantage of mutant mouse strains to obtain certain subsets in high purity, but in these cases population characteristics were always verified by further analyses of the same subsets obtained from wild-type or unrelated mutant strains. The full derivations and phenotypes of these populations are presented in detail in Table 2, and the fluorescence-activated cell sorting gates used to define and isolate the developmentally early populations are illustrated in the Appendix. Because the target gene specificity of Erg appears to overlap substantially with that of other Ets factors (Rivera et al., 1993; Murakami et al., 1993; Nikolajczyk et al., 1997), the expression of eight other Ets family transcription factor genes was monitored in parallel with Erg. RNA was extracted from all of these sorted populations and expression of Erg and eight additional Ets family members (Ets-1, Ets-2, Fli-1, PU.1, Spi-B, Elf-1, Tel and $\operatorname{GABP} \alpha$ ) were assessed by RT-PCR. The domain structures of these Ets family transcription factors and the location of the primers in the coding sequences of these genes are shown in Fig. 3.

The small numbers of cells obtained from large sorting experiments for some of these populations (for example, 20,000 cells from the thymuses of 20 immune-deficient mice) precludes nonPCR-based analysis of these populations; however, great care was taken to ensure the reproducibility and validity of all results reported here. The samples were normalized to equalize HPRT amplification products, and cycle numbers were minimized to prevent saturation of the PCR reaction. Furthermore, each PCR reaction was run at least twice, and in most cases on equivalent samples isolated from different sorting experiments.

\section{Combinatorial expression of Ets family members in $T$ and $B$ cell development}

A representative set of PCR products indicative of Ets family member expression patterns in different stages of lymphoid development is shown in Fig. 4. These results confirm that there are much higher levels of Erg in purified immature thymocytes (pops 2-4) than in mature splenic T cells (pops 9,10), as suggested by the differential screen (Fig. 2). Furthermore, these results highlight the combinatorial nature of the Ets family factor representation in different lymphoid lineages. While multiple Ets family factors are expressed in every cell population analyzed, individual Ets family factors display distinct patterns of developmental regulation. Although Ets-1 and Elf-1 are expressed stably throughout all stages tested, and GABP $\alpha$ also is expressed broadly, every other Ets factor examined here shows at least one developmental transition at which it defines a unique regulatory response.

\section{Shifts in Ets family expression define developmental transitions in the T-cell lineage}

The data shown in Fig. 4 indicate that T-lineage cells are marked from the very earliest stages of their development by strong and consistent expression of Fli-1, Ets-2 and GABP $\alpha$ in addition to the more broadly expressed Ets-1, Elf-1 and Tel. However, the earliest T-lineage cells undergo dramatic shifts in the expression of three other Ets factors that mark several regulatory transitions: Erg, PU.1 and Spi-B. These factors are expressed in the immature $\mathrm{T}$ cells but are severely repressed in all thymic $\mathrm{T}$ cells after the $\beta$-selection checkpoint (pop. $4 \rightarrow 5$ ). The transition from an uncommitted pro-T cell (Fig. 4, pop. 3)

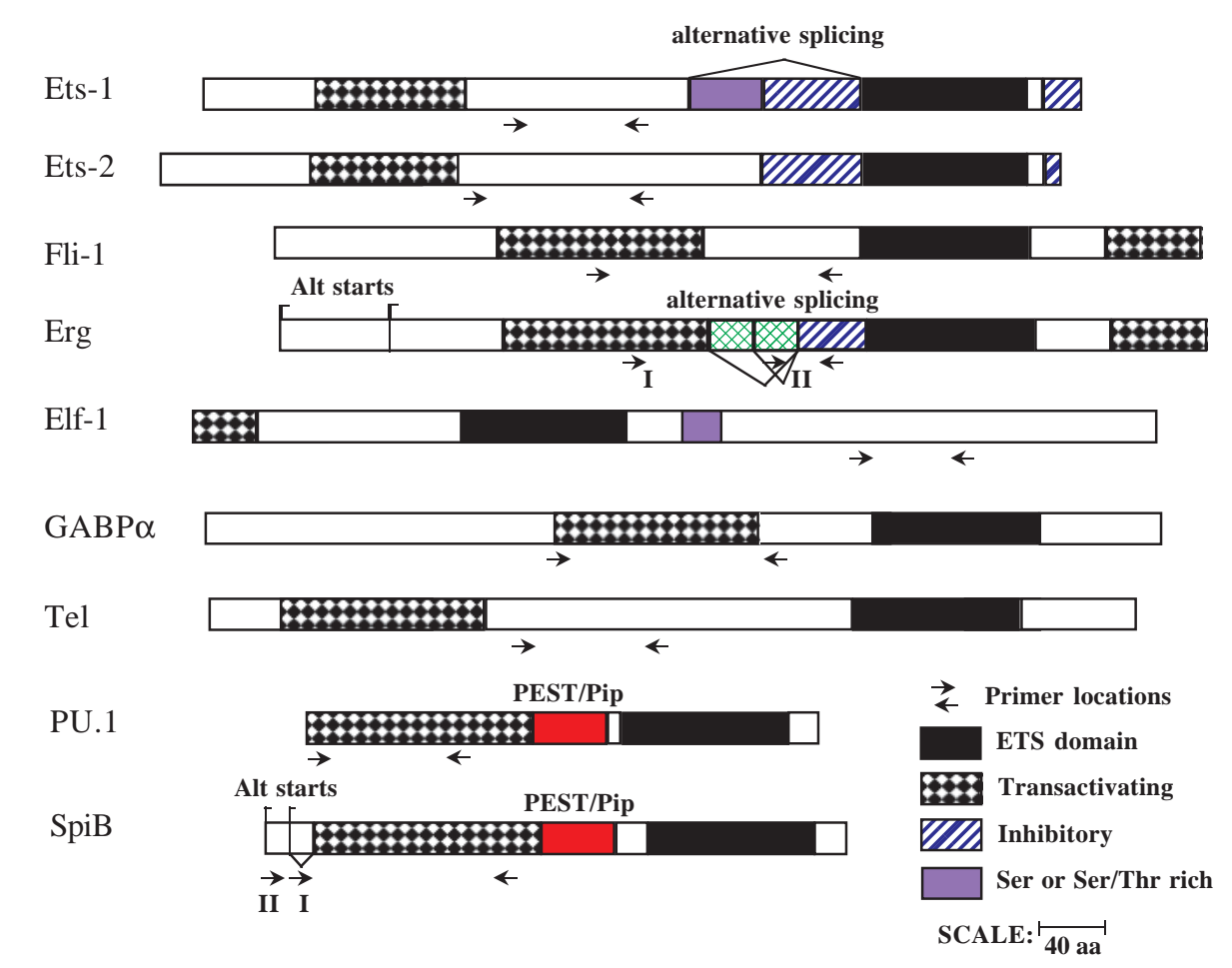

Fig. 3. Domain specificity of PCR primers for Ets factor expression analysis. PCR primers specific for each Ets factor examined here were designed to avoid cross-reactions between related family members. The functional domain structures of each factor are depicted by boxes: black solid boxes indicate the ETS DNA binding domain; diamond boxes indicate activation domains, including the Pointed (HLH) domains in Ets-1, Ets-2, Fli-1, Erg, GABP $\alpha$ and Tel; blue boxes indicate serine-rich or serine-threonine rich regions (Bassuk and Leiden, 1997); and striped boxes indicate inhibitory domains. Other domains are as specifically indicated. The location of each primer is designated by arrows underneath the boxes; in cases where more than one primer set was used, the primer sets are indicated by roman numerals. Two splice isoforms (Erg-2 and Erg-3) are amplified by Erg primer set I (as seen in Figs 6 and 7), while only the longest splice isoform (Erg-3), which includes all known exons, is amplified by Erg primer set II (as seen in Fig. 4). Both Erg and Spi-B have alternative start sites, but only the alternative start sites of Spi-B are examined here, and are amplified differentially by Spi-B1 (I) and Spi-B2 (II) primer sets. 
to a committed pro-T cell (pop. 4) is thought to occur one stage earlier than the $\beta$-selection checkpoint (RAG/SCID arrest point; asterisk in Fig. 4). This event is marked by two changes in Ets family gene expression: the downregulation of PU.1 and the temporary upregulation of Spi-B. Once the cells pass the $\beta$ selection checkpoint, Erg and Spi-B are shut off (although some transient low level expression from the Spi-B2 promoter is seen in the DP cells, pop. 6), and the essentially stable T-cell pattern of Ets factor expression is established.

Erg is also expressed in the B cell lineage in a fashion biased strongly toward the immature cells (compare Fig. 4, pops 13, 14 versus 15). None of the other factors examined show immature cell specificity for both the $\mathrm{T}$ and $\mathrm{B}$ lineages. Fli-1, which is closely related to Erg, shows a different pattern of expression in precursors of the B versus the T lineage. While Erg is shut off in the pre-T cells (pops 5,6) but expressed in the pre-B cells (pops 13, 14), Fli-1 is expressed in the pre-T cells but downregulated in the pre-B cells. In mature B cells, however, Erg is downregulated relative to its expression in pre-B cells, and Fli-1 is upregulated. Mature T cells continue to express Fli-1, but do not express Erg at all in either the thymus or the spleen.

PU.1 and Spi-B (two promoter variants) are expressed, like Erg, only at the earliest stages of T cell development. Neither is expressed in thymocytes after the $\beta$-selection checkpoint (although PU.1 and Spi-B1 are seen again occasionally in samples representing mature peripheral T cells; cf. Fig. 4, pop. 10). Both are expressed throughout B cell development (Fig. 4, pops 13-15). When examined in detail, however, it becomes apparent that Spi-B and PU.1 are not coregulated. In agreement with previous studies, PU.1 is expressed at very high levels in the myeloid subset, while Spi-B is not expressed at all in these bone-marrow derived myeloid cells (Chen et al., 1995; Su et al., 1996). Futhermore, population 3 of immature thymocytes, which is a rapidly proliferating population (Pénit et al., 1995), exhibits relatively strong expression of PU.1 but low expression of Spi-B. Spi-B expression is then sharply upregulated in population 4 as PU.1 expression drops. At the very next stage, which represents $\beta$-selection, in parallel with the shutoff of Erg, Spi-B expression from promoter 1 and any residual PU.1 expression are fully extinguished. Spi-B expression from promoter 2 is permanently silenced after the DP stage, and doesn't occur again even in the splenic $\mathrm{T}$ populations.

Several Ets factors that have been linked to normal or malignant proliferation and activation responses (Ets-1, Ets-2, Fli-1, Elf-1, Tel and GABP $\alpha$ ) show no major modulations in expression level throughout $\mathrm{T}$ cell development. The stability of this expression is surprising in view of the numerous changes in function, proliferative capacity, sensitivity to
Fig. 4. Ets factor expression analysis of lymphoid developmental subsets. RTPCR was performed on normalized samples of cDNA (see HPRT) from cells representing 16 different hematopoietic developmental stages, as described in Fig. 1 and Table 2. Specific PCR primers for the factors Ets-1, Ets-2, Erg, Fli-1, Elf-1, Tel, GABP $\alpha$, PU. 1 and two different isoforms of Spi-B were used to amplify products from each sample in parallel, which were resolved on agarose gels. The expression pattern of the PU.1/Spi-B cofactor Pip/LS-IRF is also presented here. The PCR products shown in this matrix are representative of the results of multiple experiments. The major groupings of this profile pre-NK cells, postnatal thymic subsets, fetal thymic subsets, B cell subsets and myeloid cells - are set aside by white vertical bars. The asterisk above the matrix indicates the Rag-2-l-/SCID arrest point (corresponds in normal genotype to $\beta$-selection checkpoint). The postnatal thymic populations to the left of this point were collected from Rag-2-I- mice, while those to the right were collected from either MHC-deficient mice (pop. 6) or normal mice. Results from the MHC-deficient cells have been confirmed in a sorted normal CD $8^{+} \mathrm{CD} 4^{+}$thymocyte sample. The Erg PCR products are derived from Erg primer set II. Note that the B cell samples are slightly lower in mRNA content, according to HPRT analysis, than the other samples.

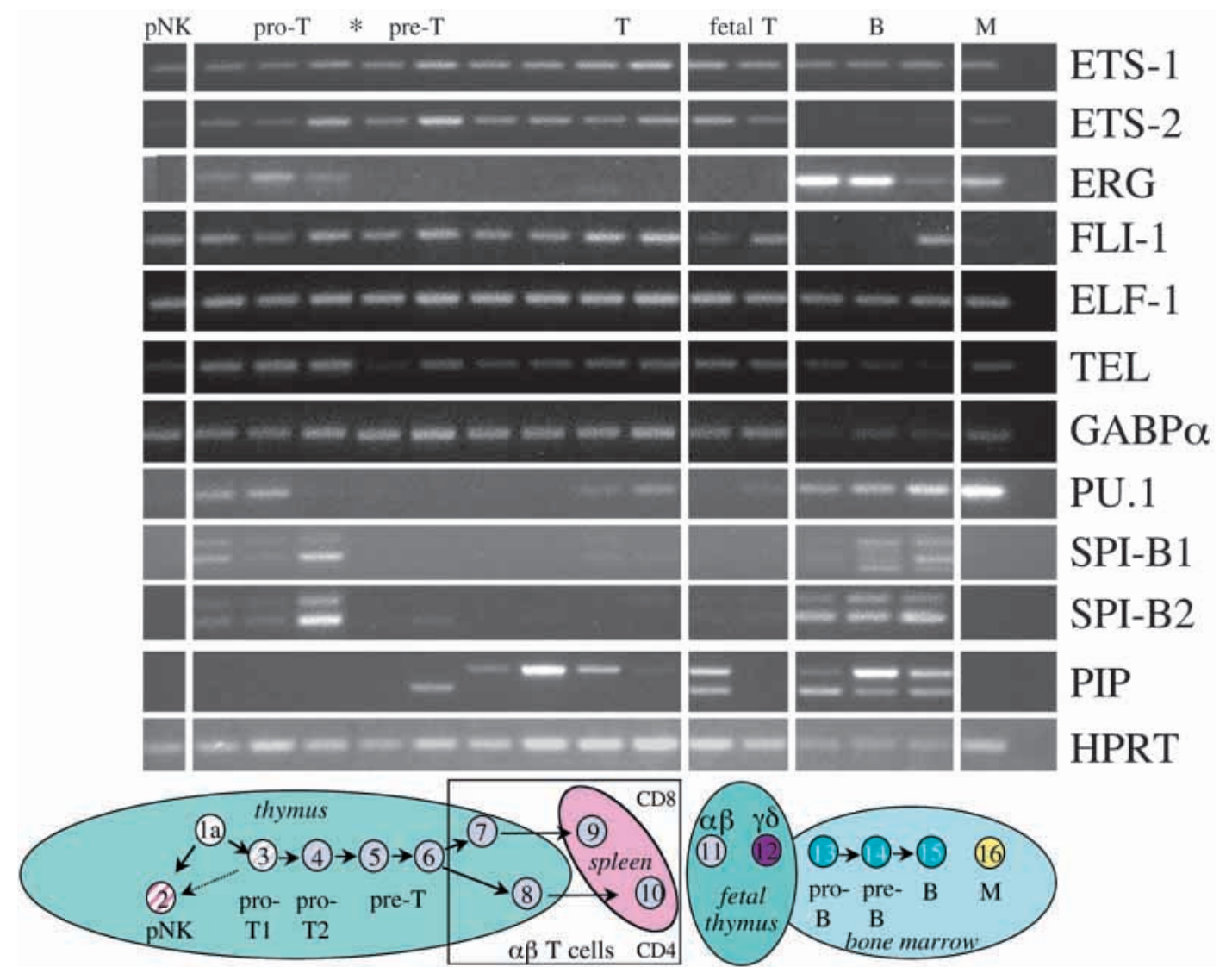


A

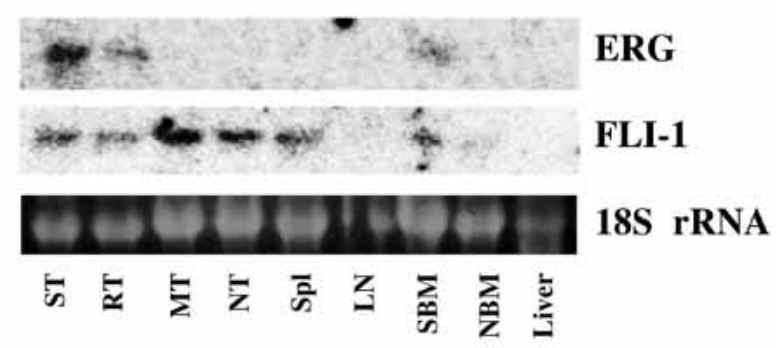

B

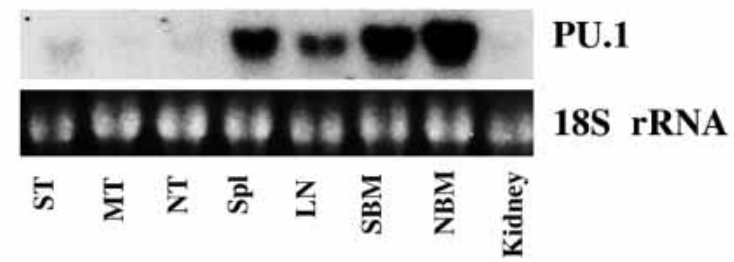

Fig. 5. Northern blot analysis of Erg, Fli-1 and PU.1 expression in hematopoietic tissues. Total RNA from hematopoietic cell suspensions were resolved on denaturing agarose gels, blotted and probed. Roughly equal loading on each blot $(20 \mu \mathrm{g} / \mathrm{lane})$ is indicated by the $18 \mathrm{~S}$ rRNA bands stained with ethidium bromide that are shown underneath the hybridization data. To obtain enough material for these blots, RNA had to be extracted from unfractionated cell populations from the indicated tissues. Approximate equivalents in terms of mixtures of pure populations are as follows. The first blot contains: SCID thymocytes (ST), representing immature cells of populations 1-3; Rag- $2^{-/-}$thymocytes (RT), representing immature cells of populations 1-4; $\mathrm{MHC}^{-/-}$thymocytes (MT), representing $>90 \%$ population 6 with $2-5 \%$ population $1-4$ cells; normal unfractionated thymocytes (NT), similar to MT except including about $15 \%$ SP cells (populations 7 and 8); normal splenocytes (SPL) depleted of red blood cells, representing mostly mature T and B cells (B>T) with some myeloid cells; lymph node cells ( $\mathrm{LN})$, representing mature $\mathrm{T}$ and B lymphocytes (T>B); SCID bone marrow (SBM), which consists of approximately $5 \%$ pro-B cells and approximately 95\% myeloid cells; normal bone marrow (NBM), with 50\% myeloid cells and $20 \%$ pre-B, immature B and mature B cells; and liver. This blot was hybridized with an Erg-specific probe, stripped, and then reprobed with a Fli-1 specific probe. The second blot contained the same samples as the first with the following changes: no Rag- $2^{-1-}$ thymocytes and kidney instead of liver. The second blot was probed with a PU.1 specific probe.

apoptosis and $\mathrm{T}$ cell receptor signaling responses that occur during these stages (Owen and Venkitaraman, 1996; Malissen and Malissen, 1996; Rothenberg et al., 1994), and suggests that these Ets factors are not essential for these changes. In general, factors that are still expressed in the T lineage after the $\beta$ selection checkpoint, such as Fli-1 and GABP $\alpha$, show little if any difference between TCR $\alpha \beta$ and TCR $\gamma \delta$ cells, between $\mathrm{CD} 4^{+}$helper cells and $\mathrm{CD} 8^{+}$killer cells, or between rapidly proliferating (pops 3,5) and resting (pops 4, 6, 9, 10) cells.

\section{Confirmation of RT-PCR results by RNA gel blot hybridization}

In order to confirm the expression patterns seen in the RT-PCR experiments, two RNA gel blots were generated using total RNA from various hematopoietic cell types (Fig. 5). The first blot was hybridized with a probe representing the Erg-specific domain and which does not cross-react with Fli-1. This blot was stripped and hybridized to an Fli-1 specific probe. The hybridization patterns of Erg and Fli-1 (Fig. 5A) support the RT-PCR analyses. Erg is observed in the immature thymocytes (lanes 1 and 2) and in the sample containing predominantly myeloid cells (lane 8), but not in the samples that consist primarily of pre-T cells (lanes 3 and 4) or mature lymphocytes (lanes 5 and 6). Fli- 1 is expressed in all of the T lineage samples (lanes 1-4) as well as in the sample enriched in mature $\mathrm{T}$ and $\mathrm{B}$ cells (lane 5). Fli-1 is seen in the bone marrow samples as well, possibly due to the substantial percentage of $\operatorname{IgM}^{+} \mathrm{B}$ cells (cf. pop. 15; see Fig. 4) or to expression by specific subtypes of nonlymphoid cells such as megakaryocytes (Mélet et al., 1996). Neither Erg nor Fli-1 is expressed in the liver, in agreement with the differential screen analysis of Erg expression (Fig. 2).

The second blot was hybridized with a PU.1-specific probe. The PU.1 expression pattern (Fig. 5B) confirms that although pre-T cells and more mature thymocytes do not express this factor, it is present in immature thymocytes, although at much lower levels than in the bone marrow (myeloid, B), splenocyte $(B>T)$, or lymph node $(T>B)$ samples. We have also isolated a full-length PU.1 cDNA clone from the SCID thymocyte library. Overall, these northern blots confirm the RT-PCR results and strengthen the evidence for differential expression of the Ets family members during hematopoietic development.

\section{Regulation of Ets family members during the multipotent progenitor to $\mathrm{T}$ lineage transition}

A key question that emerges from these analyses is whether any Ets factors are induced in pluripotent precursors as they undergo specification to the T lineage. While Fig. 4 clearly shows differences between the immature pro- $T$ cells and later T-lineage subsets, it does not show many differences that could be attributed to specification of pro-T cells (Fig. 4, cf. pops 1, 3). This may be because the 'population 1a' sample used in Fig. 4 (pop. 1) includes some transitional cells that are beginning to turn on definitive T-lineage genes such as preT $\alpha$ and RAG-1 (Wang et al., 1998a,b) (see Fig. 1 legend and Appendix). To obtain more pure populations of potentially unspecified precursors (pop. 0/1), two strategies were adopted, as shown in Fig. 6A,B. First, the multipotent progenitors (pop. 1) were sorted according to a more strict $\mathrm{Sca}-1^{\text {high }} \mathrm{CD} 24^{-}$ criterion than that used for Fig. 4 (pop. 1a), to purify them as previously described (Wang et al., 1998a,b) (Fig. 6A). Second, we made use of an additional sorting strategy to isolate a minute subset of cells that may represent even earlier precursors (Table 2, 'population 0') (Fig. 6B) (For details of these cell separations, see Appendix).

Comparison between these precursor populations and reference pro-T cell populations isolated in parallel (pop. 3,4) shows dramatic changes in the expression of several Ets factors during the transition leading to pro-T cells. First, Erg is induced de novo, and Spi-B2, Ets-2 and, to a lesser extent, Ets-1 also appear to be upregulated, as cells make the transition between population 1 and population 3. Elf-1 and PU.1 are expressed at similar levels in both populations. Only Spi-B1 (especially 
the putative splice isoform represented in the lower band in Fig. 6A) appears to decrease slightly between the multipotent lymphoid progenitor and the early $\mathrm{T}$ lineage cells. This change is quite reproducible between different, independently generated samples (Fig. 6B, data not shown).

These results are supported and extended by a limited analysis of Ets family gene expression in 'population 0' as compared to the pro-T cells (Fig. 6B). This minute population requires more complete characterization, but about half the cells in this population have properties that make them important candidates to consider for the earliest of common lymphoid progenitors in the thymus (c-kit ${ }^{+}, \mathrm{IL}^{-} 7 \mathrm{R}^{+}$, Thy-1 ${ }^{\text {neg }}$, IL-2R $\beta^{\text {neg }}$, NK1. $1^{\text {neg }}$, etc.; R. A. Diamond, H. Wang, C. Simion and E. V. Rothenberg, unpublished results). In these cells (Fig. 6B, 'prec.'; pop. 0), not only Erg but also Spi-B2 expression is very low or undetectable, much lower than in the pro-T cells. By contrast, Elf-1 and Ets-1 appear to be expressed in the precursors at similar levels to those in the pro-T cells. The data also suggest that PU.1 and Spi-B1 are expressed at much higher levels in the population 0 cells than in the pro-T cells (Fig. 6B), but the relevance of these findings awaits a population 0 sample known to be homogeneous for lymphoid precursor activity.

These results indicate that while expression of PU.1 and SpiB1 may be 'inherited' from a pluripotent precursor, expression of Erg (and perhaps Spi-B2 as well) is specifically induced as cells make the transition to the pro-T cell stage. Even so, expression of all three of these genes is severely and lastingly repressed once the cells pass through the $\beta$-selection checkpoint (with the exception of Spi-B2, transiently downregulated after $\beta$ selection, and then permanently shut off at checkpoint 2). Thus, these results distinguish pro-T cells, even after specification and to some extent after commitment, from all preceding and subsequent stages of $\mathrm{T}$ cell development.

\section{Unique pattern of Ets factor expression in pre-NK cells}

The pre-NK cells found among SCID and RAG-2 $2^{-1-}$ thymocytes (pops 2, 2a) strongly express IL-2R $\beta$ (CD122), and the lytic protein perforin (Diamond et al., 1997; Wang et al., 1998b), both of which are known to be Ets factor targets. Our results indicate that these cells express Ets-1, Fli-1,
GABP $\alpha$ and Elf-1, and modest levels of Tel and Ets-2 (Figs 4,6 ). However, they either turn off or fail to turn on Erg, PU.1 and Spi-B. To the extent that thymic pre-NK cells appear to express PU.1 or Spi-B at all (data not shown), it may be a result of contamination with 'population 0' cells, which can be present as an approximately 10-20\% minority in this population if not specifically excluded by use of the Thy-1 marker (see Table 2). Direct comparison (Fig. 6B) shows that neither PU.1, Spi-B1, Spi-B2 nor Erg is expressed at all in the pre-NK cells, when they are purified away from the population 0 cells.

\section{A distinctive Ets family regulation program in B-cell development}

We have confirmed and extended the Ets factor expression patterns in B-lineage cells seen in Fig. 4 by analyzing several additional B-lineage samples for Ets-1, Ets-2, Erg, Fli-1 and PU.1 expression, as shown in Fig. 7A. Here, independently isolated samples representing pro-B cells (pop. 13) and fully mature peripheral B cells (pop. 17; see Table 2) are compared with a DN (double negative; $\mathrm{CD} 4^{-} \mathrm{CD} 8^{-}$) thymocyte sample sorted from normal thymus (pops 1-4 and cells in the transition from 4 to 5) as a reference for comparison to the $\mathrm{T}$ cell subsets in Fig. 4. Direct comparisons of this DN thymocyte sample with the pro-T1 and pro-T2 populations sorted from Rag- ${ }^{-/-}$thymus do not show appreciable differences in Ets-1, Ets-2, Erg, or Fli-1 expression levels (data not shown). Higher PCR cycle numbers were used in Fig. 7A to achieve greater sensitivity of detection than in Fig. 4. Fig. 7A shows clearly that PU.1, Fli-1 and Ets-2 are all upregulated at a late stage during B cell maturation, while Erg is downregulated. Fli-1 and Ets-2 are expressed at low levels in pro-B cells as compared to the immature thymocytes, while PU.1 is expressed in all B cell subsets at higher levels than seen in the DN thymocyte sample (this population normally contains $<20 \%$ of cells in pops $1-3$ ).

The Ets family gene expression program in early B-lineage cells resembles that in pro-T cells in some respects, including the expression of Erg and PU.1. Although some primitive cells in the thymus preserve B-lineage developmental capability (see Fig. 1), the Erg and PU.1 expression in the precursor-like and pro- $\mathrm{T}$ populations is not a result of contamination with determined B-lineage precursors. First, the pro-T1 cells, which

Table 3. ETS factor target genes expressed during lymphocyte development

\begin{tabular}{|c|c|c|c|c|c|c|c|c|}
\hline \multirow[b]{2}{*}{ Genes } & \multicolumn{8}{|c|}{ Population } \\
\hline & 2 & 1 & 3 & 4 & 5 & ProB & PreB & $\mathrm{B}$ \\
\hline TCR-C $\beta$ & + & + & + & + & + & + & + & \pm \\
\hline $\mathrm{TCR} \alpha$ & - & - & - & - & + & - & nd (-) & nd (-) \\
\hline TdT & - & $-/+$ & + & ++ & + & + & - & - \\
\hline IL-2R $\alpha$ & - & - & + & + & - & - & + & - \\
\hline IL-2R $\beta$ & + & - & - & - & - & - & - & - \\
\hline Perforin & ++ & + & - & - & - & - & - & - \\
\hline $\operatorname{Ig} \mu$ & \pm & + & - & - & nd & + & + & + \\
\hline M-CSF-R & - & + & - & - & nd & nd & nd & nd \\
\hline
\end{tabular}

The data presented in this table are a compilation of results from our laboratory and from other studies, as reviewed in Bassuk and Leidin (1997). nd, not determined. 
Fig. 6. Induction of specific Ets factors in putative thymic precursor subsets. (A) RT-PCR was performed on thymic subsets isolated from Rag- $2^{-/-}$mice based on expression of Sca- 1 and HSA. Population 1 is Sca- $1^{+} \mathrm{HSA}^{-}$sorted on a narrow gate, and consists of putative multipotent precursors. The second population is $\mathrm{Sca}-1^{+} \mathrm{HSA}^{+}$(pop. 3,4 ), and consists of a mixture of cells which are either specified or committed to the T lineage prior to TCR rearrangement; in the Rag- $2^{-/}$, this population is heavily biased towards population 4 rather than population 3 (Diamond et al., 1997). For details of cell separation see Appendix, panel A. (B) RT-PCR also was performed on thymic subsets isolated from B6 SCID mice based on expression of Sca-1, HSA and Thy-1. Population 0 consists of Sca- $1^{-} \mathrm{HSA}^{-}$Thy-1 $1^{-}$thymocytes, and is another putative multipotent precursor population. Population 2a consists of Sca-1-HSA-Thy-1 ${ }^{+}$ thymocytes, and represents the NK cell precursors. This population is designated $2 \mathrm{a}$ to distinguish it from population 2 as seen in Fig. 4, which is a mixture of populations $2 \mathrm{a}$ and 0 , although heavily skewed towards population 2 . The third population $(3,4)$ is Sca-

$1^{+} \mathrm{HSA}^{+}$Thy $-1^{+}$, and consists of a mixture of cells which are either specified or committed to the $\mathrm{T}$ lineage prior to TCR rearrangement. This population in the B6 SCID mice, however, is heavily biased towards population 3 rather than population 4 (Diamond et al., 1997). For details of cell separation, see Appendix, panel B. The PCR products shown for each primer set (PU.1, Spi-B1, Spi-B2, Ets-1, Erg, Elf-1 and HPRT) are representative of multiple experiments.

express both factors, do not show B-cell precursor activity (reviewed by Shortman and Wu, 1996; Zúñiga-Pflücker and Lenardo, 1996). Second, in a more direct assay, we have determined that the levels of Erg and PU.1 in purified pro-T cells exceed those that could be attributed to contamination with B cell precursors. These results are shown in Fig. 7B. Using sorted DP pre-T cell cDNA as a base lacking Erg or PU.1 expression (Fig. 7B, lane 2), we have mixed pro-B cell cDNA
Fig. 7. Divergent regulation of Ets family members in B cell development. (A) RT-PCR was performed on samples separate from those exhibited in Fig. 4 in order to further characterize the $\mathrm{B}$ cell developmental regulation of Ets family members. The DN-T sample (denoted pop. 3,4 ) was obtained by sorting $\mathrm{CD}^{-} \mathrm{CD}^{-} \mathrm{CD}^{-}$ thymocytes from normal mice, and contains all of the precursor and pro-T populations in the thymus; however, the bulk of these cells have already committed to the T lineage (pop. 4). The pro-B cell sample (which is roughly equivalent to pop. 13) was obtained from Rag- $2^{-1-}$ mice, and the third population represents $\mathrm{B}$ cells from normal spleen, based on expression of B220 but not TCR $\alpha \beta$. These cells are primarily IgM-bearing mature B cells. The likely developmental relationships between these cells are depicted below the PCR product results; the CLP (common lymphoid precursor) is included for this purpose but has not been isolated in these experiments. The samples are normalized to HPRT as shown.

(B) RT-PCR mixing experiment. RT-PCR was performed on cDNA from DP cells (pop. 6) mixed with B6 SCID pro-B cDNA (pop. 13) at ratios of 99:1, 95:5 and 80:20 to determine whether the signals seen in the SCID thymocyte populations could be due to contamination with pro-B cells. These reactions were run in parallel with reactions using cDNA from a sorted SCID thymocyte sample representing population 3, from a sorted DP sample without any pro-B cell cDNA added, and from a sorted B6 SCID pro-B sample. PCR reactions were as for Fig. 7A, using the PU.1, ERG and HPRT primers. The mb-1 primers were used as a measure of a B cell specific transcript known to be expressed in pro-B cells but in neither SCID thymocytes nor DP thymocytes (Wang et al., 1998a). Lane 1 (numbered from the left): B6-SCID thymocyte cDNA, Sca- $1^{+}$HSA ${ }^{+}$Thy- $1^{+}$(pop. 3); lane 2: MHC ${ }^{-1-}$ thymocyte cDNA, CD4 ${ }^{+} \mathrm{CD}^{+}$(pop. 6); lane 3: 99:1 ratio of DP thymocyte cDNA to B6 SCID pro-B cell cDNA; lane 4: 95:5 ratio of DPT:pro-B; lane 5: 80:20 ratio of DP-T:pro-B; lane 6: B6-SCID B220+ CD19+ pro-B cell cDNA (pop. 13). 
from SCID bone marrow (lane 6) with DP cDNA at ratios from $1-20 \%$ of the total (lanes 3-5), and compared the resulting yields of Erg and PU.1 cDNA with those from purified pro-T1 cells (lane 1). An internal standard of mb-1 (Ig- $\alpha$, CD79a) cDNA, which is B cell specific (Wang et al., 1998a), shows that the level of contamination of the pro-T cells with B lineage precursors even as immature as these pro-B cells is below $1 \%$, in agreement with the high purity of these fractions as measured by flow cytometry (see legend to Table 2). However, the expression of Erg and PU.1 in the pro-T cells exceeds the level observed with deliberate contamination levels of $5 \%$ or $20 \%$, respectively. Thus the expression of Erg and PU.1 is truly common to precursors in both the $\mathrm{B}$ cell and the $\mathrm{T}$ cell developmental programs.

\section{PU.1/Spi-B cofactor regulation in T and B cell development}

PU.1 and Spi-B are known to interact with the lymphocytespecific IRF (interferon-response factor) transcription factor family member PIP (PU.1 interaction partner)/LS-IRF (IRF4, NF-EM5). This factor functions as a potent transcriptional coactivator on Ig gene enhancers (Eisenbeis et al., 1995; Su et al., 1996) but is not required for PU.1 activation of myeloid target genes. To ascertain whether this partner is available in all the lymphoid subsets that express PU.1 or Spi-B, we examined these subsets for PIP expression as well, as shown in Fig. 4. Our PIP-specific primers amplify two products; the upper band is the expected size. The possibility that the lower band represents an alternatively spliced form is currently under investigation. Our results show that in the B-lineage cells, PIP is coexpressed with both PU.1 and Spi-B. As expected, it is not seen in the myeloid subset examined here. Interestingly, PIP is also absent from the immature thymocyte subsets where PU.1 and Spi-B are expressed, but present in the pre-T (pops 5, 6) and mature SP thymocytes (pops 7-11), which lack PU.1 and Spi-B. This suggests that PU.1 and Spi-B may have different roles in the immature thymocytes than in developing $\mathrm{B}$ cells.

\section{DISCUSSION}

These experiments demonstrate that Ets family transcription factor genes are targets of intricate, lineagecell stages (see text and Fig. 6). specific developmental regulation during the specification, commitment and differentiation of various classes of lymphocytes. Erg, Spi-B, PU.1, Fli-1 and, to a lesser extent, Ets-2 are each subject to a different program of positive and negative regulation in various stages of lymphoid development. Fig. 8 provides a summary of the expression patterns of each of these factors as a function of lymphocyte differentiation. Thus, the regulatory regions of multiple Ets family genes are differential targets of the regulators that confer cell-type identity on developing lymphocytes.

As summarised explicitly in Fig. 8, the points of inflection in Ets family gene regulation reveal a particularly dynamic period early in T cell development, a unique sequence of stages when three genes are active (Erg, Spi-B and PU.1) that are not expressed significantly at any later stage of $\mathrm{T}$ cell development. This period includes the onset of expression of multiple $\mathrm{T}$ lineage effector genes (i.e. T lineage specification); the loss of developmental plasticity (commitment); and the onset of TCR gene rearrangement. This regulatory phase ends when the cells succeed in passing the $\beta$-selection checkpoint, and after this

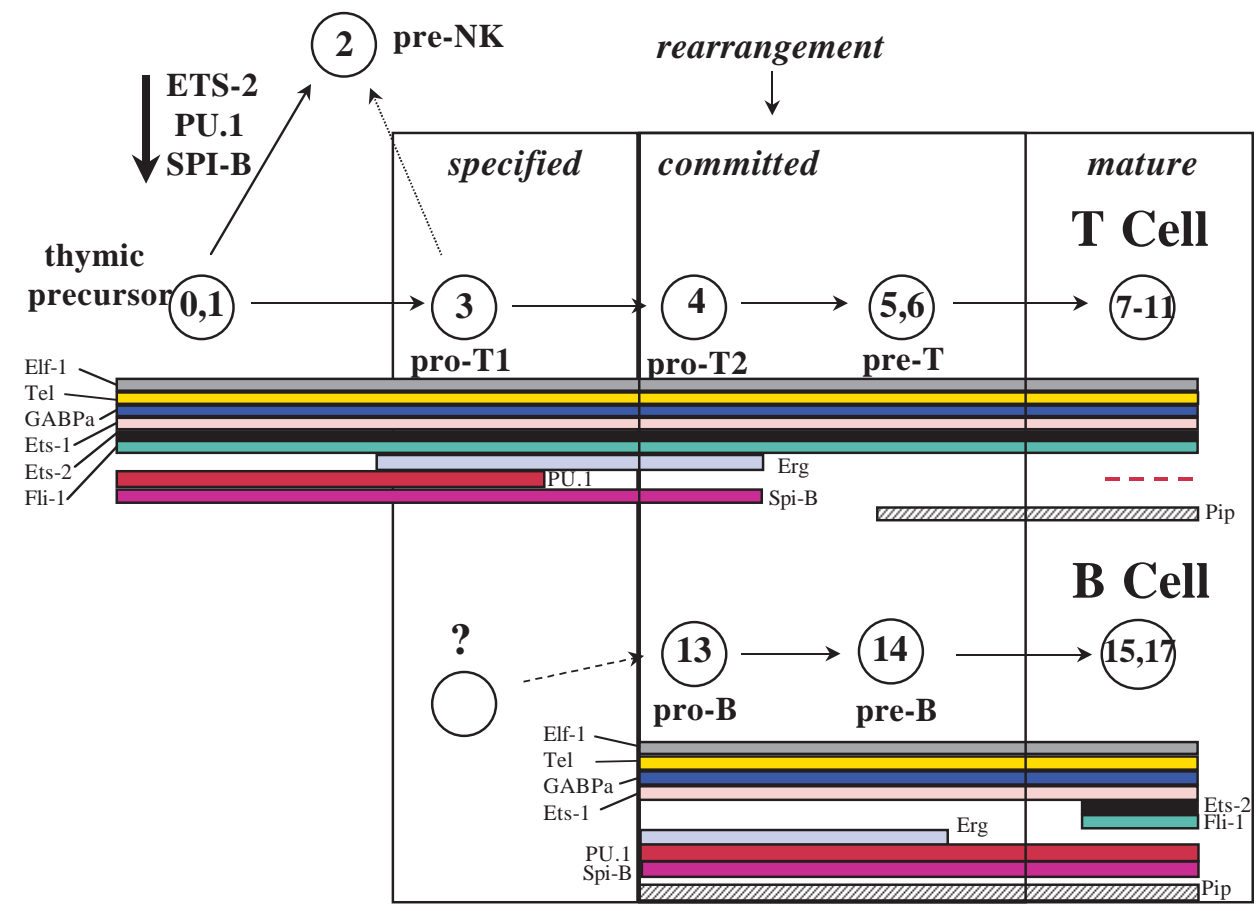

Fig. 8. Summary of Ets factor regulation during lymphoid specification and commitment. A diagrammatic representation of the modulation of Ets factor mRNA expression throughout various stages of B cell, T cell and NK cell differentiation. The white circles represent the isolated populations according to the same numbering scheme used throughout this paper, and arrows indicate developmental progression. The white circle without a number followed by a dashed arrow (bottom left) refers to a hypothetical pro-B1 population which is specified but not yet committed to the B lineage, analogous to the pro-T1 lineage, since the precise timing of B-lineage commitment is not well resolved. The large black arrow pointing down (top left) indicates a decrease in the factor indicated for the precursor to pre-NK cell transition. The presence or absence of different Ets factors at each stage as monitored by relatively low PCR cycle number is depicted by colored bars, with each color representing a different Ets factor, for the T cell developmental stages (upper half of figure) and the B cell developmental stages (lower half of figure). Pip, an IRF transcription factor family member and cofactor for PU.1 and Spi-B, is also depicted. The two isoforms of Spi-B are not separated here for simplicity, but do show some differences in expression in the earliest $\mathrm{T}$ 
checkpoint there are no significant changes in the expression of the Ets factors monitored here. One of the important new findings of this work is the identification of a small set of transcriptional regulators that are expressed specifically during this important period of cell fate determination. Two specific changes in expression of these factors - the onset of Erg expression, and the shutoff of PU.1 expression - respectively mark the specification and lineage commitment events for $\mathrm{T}$ cell precursors.

More limited data on Ets gene expression have been available previously (Prasad et al., 1994; Chen et al., 1995; Su et al., 1996; Ford et al., 1996; Bassuk and Leiden, 1997; Lenny et al., 1997; Nikolajczyk et al., 1997), but this is the first time that purified populations of primary lymphocytes at successive stages of differentiation have been compared in detail. To the extent that previous work has considered these cell types, the results have been generally consistent with ours (Bassuk and Leiden, 1997; Nikolajczyk et al., 1997; Lenny et al., 1997; Su et al., 1996). On the other hand, in previous studies the conclusion of T- or B-lineage specificity has often been based on analyses of immortal, malignantly transformed cell lines. Such lines, especially the T cell lines used, bear a very doubtful relationship to any natural stages of $\mathrm{T}$ cell development. Even if Ets expression were not perturbed during the establishment of the cell line, it would be important to know the stage at which cells were immortalized, because our results show substantial changes in the expression of certain Ets genes in the course of $\mathrm{T}$ and B cell development, not a fixed 'lineage-specific' expression pattern. Thus, the absence of a factor like Erg from certain $\mathrm{T}$ cell lines (Rivera et al., 1993) does not preclude its playing an important role in early stages of differentiation in primary $\mathrm{T}$ cells.

\section{Ets factor expression during $T$ cell specification and commitment}

The distinction between the Ets factor expression profiles in 'early' and 'late' stages of T- and B-cell development is one of the most important results from our work. The 'early' phase of Ets family gene expression ends just when the thymocytes undergo a major physiological change (Rothenberg et al., 1994), as they enter a period when their fate becomes dependent on signaling through their T-cell receptor complexes. It is striking that Ets family gene expression is stable thereafter. Although there are numerous substantial differences in activation physiology and functional competence between cells in the DP thymocyte population (pop. 6) and SP thymocytes (pops 7, 8) and peripheral T cells (pops 9, 10) (Rothenberg, 1992; Rothenberg et al., 1994; Simon et al., 1996; Rincon and Flavell, 1996; Vanhecke et al., 1995; Kishimoto and Sprent, 1997), these cell types express complements of Ets factors that are much more similar to each other than to the Ets factors expressed before $\beta$-selection (pops 1, 3, 4). The dynamic and distinctive Ets family gene regulation in 'earlystage' $\mathrm{T}$ cell precursors therefore reflects regulatory events that are qualitatively distinct from the life/death selection pressures that act on thymocytes later. We propose that the 'early' Ets family gene expression changes are a response to the process that narrows the developmental potential of the pluripotent precursor, to culminate in lineage commitment.

Something of the nature of this process is revealed by the transience of 'early' Ets gene expression. The sharp onset of Erg expression around the time of the specification event(s) gives evidence for a discrete regulatory event at the beginning of this critical period. This is when we have found that multiple T-lineage specific target genes are upregulated or begin to be expressed (Wang et al., 1998a,b). Because the cells in 'population 0' do not appear to express Spi-B from the Spi-B2 promoter, it is possible that activation of this promoter is also associated with some aspect of T-lineage specification (cf. 'ragged' onset of T lineage gene expression in Wang et al., 1998a,b). But neither Erg nor Spi-B2 induction represents the acquisition of a mature $\mathrm{T}$ cell property, since both Erg and Spi-B will be shut off soon after lineage commitment, long before $\mathrm{T}$ cell maturation is complete, while T-lineage specific gene expression continues. What kind of function could their transient expression confer?

Work to answer this question is now underway, but it is worth noting one speculative possibility for the role of Erg during early $\mathrm{T}$ and $\mathrm{B}$ cell differentiation. The Ets family members bind to DNA and transactivate transcription as monomers. However, Erg is among a number of Ets family members that can hetero- and homodimerize, and this is thought to lead to an inability to bind DNA (Carrère et al., 1998; Kwiatkowski et al., 1998). Thus, although Erg is normally a trans-activator with growth-stimulating properties (Hart et al., 1995; Duterque-Coquillaud et al., 1993; Rivera et al., 1993), it is conceivable that in cells undergoing lineage commitment, Erg could act as a stagespecific inhibitor of transactivation by certain other Ets family members. This type of inhibition may provide a mechanism for maintaining developmental plasticity, analogous to the role of Id in bHLH-mediated development (Bain and Murre, 1998).

The shutoff of PU.1 expression coincides remarkably well with the transition at which commitment occurs (Figs 1, 8). This result is exciting because PU.1 is known to be essential for development of cells in two alternative lineages, myeloid and $\mathrm{B}$, and its activity is directly implicated in the expression of macrophage and B cell target genes (Tenen et al., 1997; Scott et al., 1994, 1997; McKercher et al., 1996; Olson et al., 1995; Fitzsimmons and Hagman, 1996; Reya and Grosschedl, 1998). As long as it is present, PU.1 may preserve the ability to express such non-T genes. Alternatively, PU.1 could maintain some viability or growth-control property inherited from the hematopoietic stem cell (Voso et al., 1994; Scott et al., 1994; Anderson et al., 1998) through the early stages of Tlineage differentiation, perhaps associated with expression of the stem cell factor receptor c-kit (Table 2; also see Diamond et al., 1997). PU.1 mutant mice have a severe defect in T cell development as well as in macrophage and B cell development (Scott et al., 1994; McKercher et al., 1996), and our discovery that PU.1 expression extends into early stages of $\mathrm{T}$ cell development suggests that an essential activity of PU.1 may 
continue for a short time even after $\mathrm{T}$ lineage specification, as opposed to being needed only in common precursors of these cells.

\section{Distinct regulatory programs for NK lineage expression of Ets family genes}

NK cells are close relatives of T cells, but the generation of the NK-like 'pre-NK cells' is associated with a loss of several Ets factors (for properties of these cells, see Diamond et al., 1997; Carlyle et al., 1997; Wang et al., 1998b). Interestingly, a similar loss of specific class A bHLH factors is seen in the pre-NK cells as well (M. Anderson and E. Rothenberg, unpublished). If they truly share common precursors with $\mathrm{T}$ cells (i.e. population 1), as is generally believed, then these cells must not only lose expression of Spi-B and PU.1 entirely, but also downregulate Ets- 2 and Tel. The trigger for these changes is unknown. Pre-NK cells do express the known Ets target genes perforin (Zhang and Lichtenheld, 1997) and CD122 (Lin et al., 1993) (see Table 3), presumably by using Ets-1, Fli-1, Elf-1 or GABP $\alpha$ (Diamond et al., 1997; Wang et al., 1998b). The impression that they may be relatively Ets-deficient is strengthened by the report that Ets$1^{-/-}$mice exhibit quasi-normal hematopoietic development with the exception of the NK cells, which are severely deficient (Barton et al., 1998). Thus, T and B cells in these animals may have compensating Ets factors that are absent in the NK cells.

\section{Ets factors as upstream regulators and downstream targets}

These findings provide a starting point for investigating how the changing combinations of Ets factors in cells may affect their expression of lymphoid-specific Ets target genes (Bassuk and Leiden, 1997). A great variety of genes that are differentially regulated during $\mathrm{T}$ cell and $\mathrm{B}$ cell development are targets of regulation by Ets family genes, as illustrated by the examples in Table 3. In many cases, in vitro binding and transactivation assays have suggested that Ets family factors play promiscuous and redundant roles in gene expression (Bassuk and Leiden, 1997). Ets-1 gene knockout phenotypes also show that some genes regulated by Ets- 1 in vitro can be regulated by other factors in vivo (Muthusamy et al., 1995; Bories et al., 1995). In vitro, the ability of the Ets-1 factor to drive expression of disparately regulated genes has often made the Ets family role in gene expression appear to be merely a 'scaffolding function', facilitating interaction with other proteins (Crépieux et al., 1994), without any developmental information content. Thus, in this context, the strikingly precise and dramatic regulation of different Ets family members in successive stages of lymphocyte development that we see comes as a surprise. A similar Etsfamily factor specificity may be exercised in certain developing neurons (Lin et al., 1998). These results are a reminder that at least in the regulatory milieu of cells at critical transition points, various Ets family members are unlikely to be equivalent.

Many of the Ets factors themselves are targets of auto- and cross-regulation, resulting in complex regulatory networks of multiple family members. It may be, in systems like this, that the relative levels of the factors are critical to stabilize the resulting gene expression patterns, so that even slight elevations of one competing factor over another can tip the balance, leading to a progressive downregulation of one factor and upregulation of another (Cross and Enver, 1997; Rothenberg et al., 1999). The downregulation of specific subsets of Ets factors in each lymphoid cell type after commitment (Ets-2, Spi-B and PU.1 in NK cells; Erg, PU.1 and Spi-B in T cells; and Erg in B cells) might be the result of such a mechanism. Such scenarios remain to be tested in our system.

The impact of individual Ets factors on the steps of the lymphoid differentiation process can now be tested rationally by perturbation studies. The work presented here indicates three strategic considerations that would not have been evident before. First, Erg, Spi-B and PU.1 - factors not previously considered in the context of T-lineage differentiation - should be tested for specific positive roles in precursor expansion and/or T-lineage specification, early in $\mathrm{T}$ cell development. Second, by contrast, multiple Ets factors expressed by mature $\mathrm{T}$ cells become less attractive candidates for individual perturbation, since they show so little developmental inflection in their own expression that they may simply constitute a stable and/or redundant pool of generalized Ets function for T-lineage cells. Finally, the extinction of Erg, Spi-B and PU.1 expression at the $\beta$ selection checkpoint raises the possibility that continued expression of these factors would be incompatible either with stabilization of $\mathrm{T}$ cell lineage identity or with the physiology of T-cell-receptor-dependent repertoire selection. Accordingly, studies to test the impact of the forced expression of these factors are now in progress.

In summary, the major developmental stages of $\mathrm{T}$ and $\mathrm{B}$ cell differentiation are defined by expression of overlapping but distinct combinations of Ets family members. Erg is sharply upregulated in $\mathrm{T}$ cell precursors at the time of specification to the $\mathrm{T}$ lineage. It remains to be seen whether Erg has a role in activating the $\mathrm{T}$ cell gene expression program or in destabilizing alternative, precursor gene expression states. The silencing of Erg, PU.1 and Spi-B just after commitment to the $\mathrm{T}$ lineage could be as important in T cell development as their activation, especially since PU.1 and Spi-B are already expressed at low levels in the earliest thymocyte precursors. Furthermore, the precise and unique timing of PU.1 downregulation suggests an essential relevance to T-lineage commitment. The link between these combinations of Ets family members and potential downstream target genes remains to be studied. The results presented here, though, at least predict that the promoter and enhancer elements of these Ets factors will themselves be highly specialized targets of developmentally specific regulators. In future work, combined approaches integrating upstream and downstream targets of the Ets factors should yield a wealth of insight into the transcription factor networks which establish and maintain the lymphoid lineages. 
A

\section{Rag-2 ${ }^{-1-}$ Thymus}
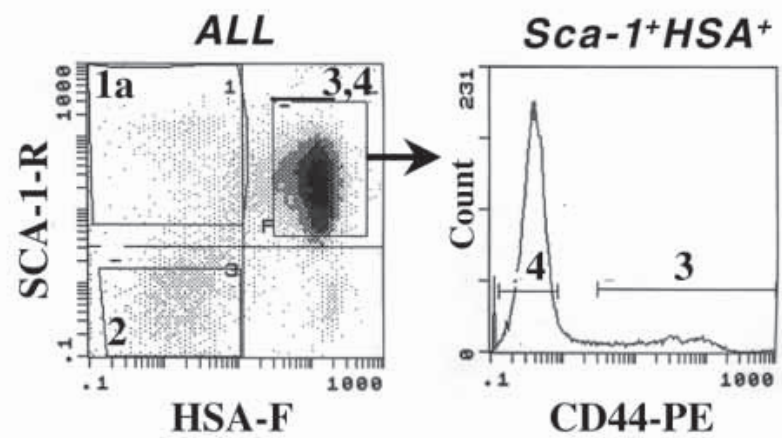

Sca-1 +

HSA - int

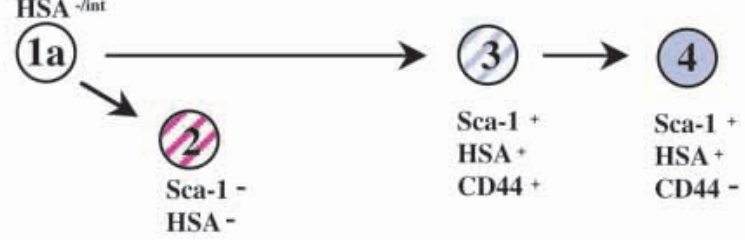

B

B6 SCID Thymus
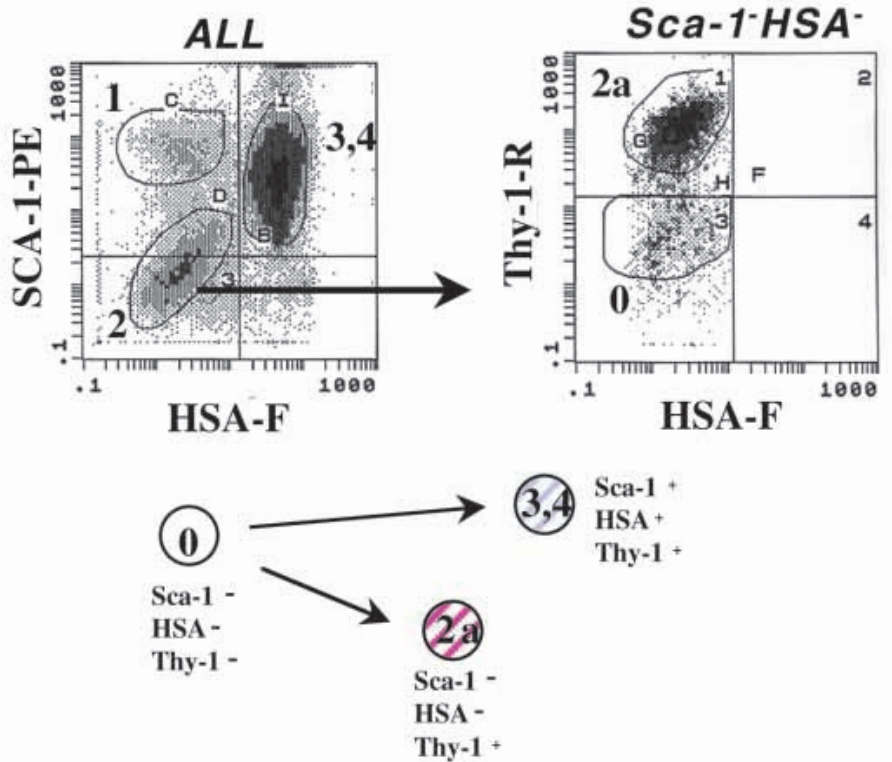

C

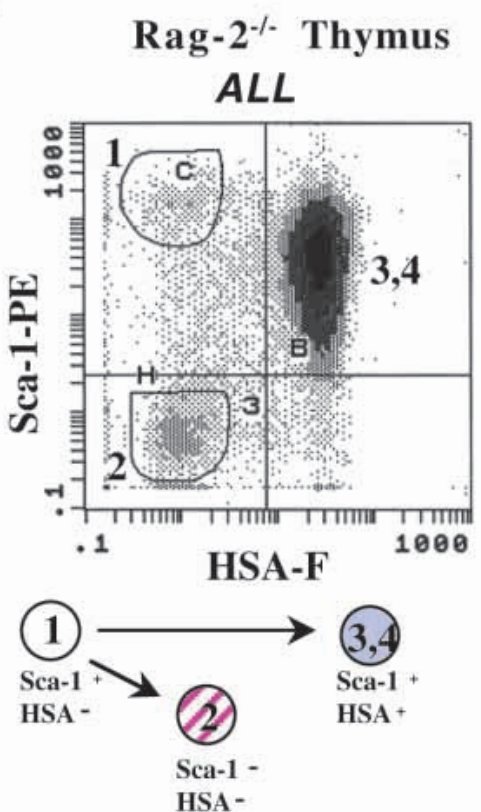

D

B6 SCID Bone Marrow $\mathrm{B220}^{+}$

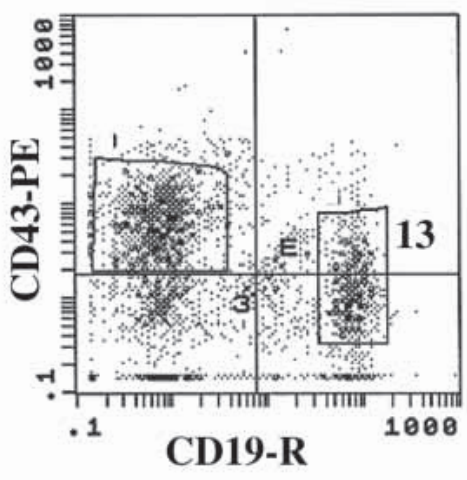

Normal Bone Marrow ALL
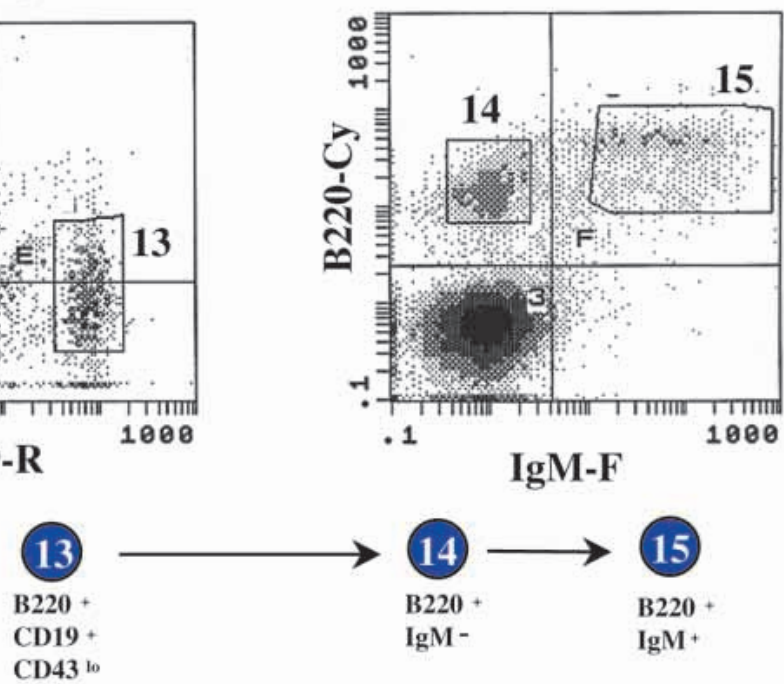

\section{APPENDIX}

Flow cytometry sorting gates used to collect the populations examined in (A) Fig. 4, (B) Fig. 6B, (C) Fig. 6A and (D) Fig. 7. Colors and numbers are consistent with all other figures and tables. Note the difference in sorting gates between pops 1a (A) and 1 (C) and pops 2a (B) and 2 (A). Pop. 1 is indicated in (B) but low cell numbers prohibited collection of all four populations from this sample.

The authors would like to thank Hua Wang and Susannah Barbee for generous donations of several sorted cell samples and the other members of the laboratory for helpful discussions. We are grateful to Dr Ellen Robey for providing the MHC-deficient mice, to Ted Biondi and Leanne Roshanda for valuable help with the Q-BOT arraying robot, to Patrick Koen of the Caltech Flow Cytometry/Cell Sorting Facility for excellent assistance with the cell sorting, to the Caltech Biopolymer Synthesis Facility for providing numerous high-quality oligonucleotides, and to the Caltech Sequencing Facility for expeditious sequence analysis. We would also like to thank Eric Davidson and Jonathan Rast for critical reading and thoughtful comments on the manuscript. This work was supported by the Stowers Institute for Medical Research and by USPHS grants AI34041 and AG13108. 


\section{REFERENCES}

Anderson, K. L., Smith, K. A., Conners, K., McKercher, S. R., Maki, R. A. and Torbett, B. E. (1998). Myeloid development is selectively disrupted in PU.1 null mice. Blood 91, 3702-3710.

Bain, G. and Murre, C. (1998). The role of E-proteins in B- and Tlymphocyte development. Semin. Immunol. 10, 143-153.

Barton, K., Muthusamy, N., Fischer, C., Ting, C.-N., Walunas, T. L., Lanier, L. L. and Leiden, J. M. (1998). The Ets-1 transcription factor is required for the development of natural killer cells in mice. Immunity $\mathbf{9 , 5 5 5 -}$ 563.

Bassuk, A. G. and Leiden, J. M. (1997). The role of Ets transcription factors in the development and function of the mammalian immune system. Adv. Immunol. 64, 65-104.

Bories, J.-C., Willerford, D. M., Grévin, D., Davidson, L., Camus, A., Martin, P., Stéhelin, D. and Alt, F. W. (1995). Increased T-cell apoptosis and terminal B-cell differentiation induced by inactivation of the Ets-1 proto-oncogene. Nature 377, 635-638.

Carlyle, J. R., Michie, A. M., Furlonger, C., Nakano, T., Lenardo, M. J., Paige, C. J. and Zúñiga-Pflücker, J. C. (1997). Identification of a novel developmental stage marking lineage commitment of progenitor thymocytes. J. Exp. Med. 186, 173-182.

Carrère, S., Verger, A., Flourens, A., Stehelin, D. and DuterqueCoquillaud, M. (1998). Erg proteins, transcription factors of the Ets family, form homo, heterodimers and ternary complexes via two distinct domains. Oncogene 16, 3261-3268.

Chen, H., Ray-Gallet, D., Zhang, P., Hetherington, C. J., Gonzalez, D. A., Zhang, D. E., Moreau-Gachelin, F. and Tenen, D. G. (1995). PU.1 (Spi-1) autoregulates its expression in myeloid cells. Oncogene 11, 15491560.

Chen, H.-M., Zhang, P., Voso, M. T., Hohaus, S., Gonzalez, D. A., Glass, C. K., Zhang, D.-E. and Tenen, D. G. (1995). Neutrophils and monocytes express high levels of PU.1 (Spi-1) but not Spi-B. Blood 85, 29182928.

Chen, H., Gonzales, D. A., Radomska, H. S., Voso, M. T., Sun, Z., Zhang, P., Zhang, D.-E. and Tenen, D. G. (1998). Two promoters direct expression of the murine Spi-B gene, an Ets family transcription factor. Gene 207, 209218 .

Crépieux, P., Coll, J. and Stehelin, D. (1994). The Ets family of proteins: weak modulators of gene expression in quest for transcriptional partners. Crit. Rev. Oncog. 5, 615-638.

Cross, M. A. and Enver, T. (1997). The lineage commitment of haemopoietic progenitor cells. Curr. Opin. Genet. Dev. 7, 609-613.

Degnan, B. M., Degnan, S. M., Naganuma, T. and Morse, D. E. (1993). The ets multigene family is conserved throughout the Metazoa. Nucl. Acids Res. 21, 3479-3484

Diamond, R. A., Ward, S. B., Owada-Makabe, K., Wang, H. and Rothenberg, E. V. (1997). Different developmental arrest points in RAG2 I- and scid thymocytes on two genetic backgrounds: developmental choices and cell death mechanisms before TCR gene rearrangement. J. Immunol. 158, 4052-4064.

Duterque-Coquillaud, M., Neil, C., Plaza, S. and Stéhelin, D. (1993). New human erg isoforms generated by alternative splicing are transcriptional activators. Oncogene 8, 1865-1873.

Eisenbeis, C. F., Singh, H. and Storb, U. (1995). Pip, a novel IRF family member, is a lymphoid-specific, PU.1-dependent transcriptional activator. Genes Dev. 9, 1377-1387.

Ernst, P., Hahm, K., Trinh, L., Davis, J. N., Roussel, M. F., Turck, C. W. and Smale, S. T. (1996). A potential role for Elf-1 in terminal transferase gene regulation. Mol. Cell. Biol. 16, 6121-6131.

Fitzsimmons, D. and Hagman, J. (1996). Regulation of gene expression at early stages of B-cell and T-cell differentiation. Curr. Opin. Immunol. 8, 166-174.

Ford, A. M., Bennett, C. A., Healy, L. E., Towatari, M., Greaves, M. F. and Enver, T. (1996). Regulation of the myeloperoxidase enhancer binding proteins Pu1, C-EBP $\alpha,-\beta$ and $-\delta$ during granulocyte-lineage specification. Proc. Natl. Acad. Sci. USA 93, 10838-10843.

Hart, A. H., Corrick, C. M., Tymms, M. J., Hertzog, P. J. and Kola, I. (1995). Human ERG is a proto-oncogene with mitogenic and transforming activity. Oncogene 10, 1423-1430.

Hoffman, E. S., Passoni, L., Crompton, T., Leu, T. M. J., Schatz, D. G., Koff, A., Owen, M. J. and Hayday, A. C. (1996). Productive T-cell receptor $\beta$-chain gene rearrangement: coincident regulation of cell cycle and clonality during development in vivo. Genes Dev. 10, 948-962.
Hunte, B. E., Capone, M., Zlotnik, A., Rennick, D. and Moore, T. A (1998). Acquisition of CD24 expression by Lin $^{-}$CD $43^{+}$B $220^{\text {low }}$ ckit $^{\text {hi }}$ cells coincides with commitment to the B cell lineage. Eur. J. Immunol. 28, 38503856.

Ingelbrecht, I. L., Mandelbaum, C. I. and Mirkov, T. E. (1998). Highly sensitive northern hybridization using a rapid protocol for downward alkaline blotting of RNA. BioTechniques 25, 420-426.

Jenkinson, E. J. and Owen, J. J. T. (1990). T cell differentiation in thymus organ cultures. Semin. Immunol. 2, 51-58.

Kishimoto, H. and Sprent, J. (1997). Negative selection in the thymus includes semimature T cells. J. Exp. Med. 185, 263-271.

Kondo, M., Weissman, I. L. and Akashi, K. (1997). Identification of clonogenic common lymphoid progenitors in mouse bone marrow. Cell 91, 661-672.

Kwiatkowski, B. A., Bastian, L. S., Bauer, T. R., Jr., Tsai, S., ZielinskaKwiatkowska, A. G. and Hickstein, D. D. (1998). The ets family member Tel binds to the Fli- 1 oncoprotein and inhibits its transcriptional activity. $J$. Biol. Chem. 273, 17525-17530.

Lai, Z. C., Fetchko, M. and Li, Y. (1997). Repression of Drosophila photoreceptor cell fate through cooperative action of two transcriptional repressors Yan and Tramtrack. Genetics 147, 1131-1137.

Lenny, N., Westendorf, J. J. and Hiebert, S. W. (1997). Transcriptional regulation during myelopoiesis. Mol. Biol. Reports 24, 157-168.

Li, Y., Hayakawa, K. and Hardy, R. R. (1993). The regulated expression of $\mathrm{B}$ lineage associated genes during $\mathrm{B}$ cell differentiation in bone marrow and fetal liver. J. Exp. Med. 178, 951-960.

Li, Y.-S., Wasserman, R., Hayakawa, K. and Hardy, R. R. (1996) Identification of the earliest B lineage stage in mouse bone marrow. Immunity 5, 527-535.

Lin, E. Y., Bhat, N. K., John, S., Queale, W. S. and Leonard, W. J. (1993) Characterization of the human interleukin-2 receptor beta-chain gene promoter: regulation of promoter activity by ets gene products. Mol. Cell. Biol. 13, 6201-6210.

Lin, J. H., Saito, T., Anderson, D. J., Lance-Jones, C., Jessell, T. M. and Arber, S. (1998). Functionally related motor neuron pool and muscle sensory afferent subtypes defined by coordinate ETS gene expression. Cell 95, 393-407.

Malissen, B. and Malissen, M. (1996). Functions of TCR and pre-TCR subunits: lessons from gene ablation. Curr. Opin. Immunol. 8, 383-393.

McKercher, S. R., Torbett, B. E., Anderson, K. L., Henkel, G. W., Vestal, D. J., Baribault, H., Klemsz, M., Feeney, A. J., Wu, G. E., Paige, C. J. and Maki, R. A. (1996). Targeted disruption of the PU.1 gene results in multiple hematopoietic abnormalities. EMBO J. 15, 5647-5658.

Mélet, F., Motro, B., Rossi, D. J., Zhang, L. and Bernstein, A. (1996) Generation of a novel Fli-1 protein by gene targeting leads to a defect in thymus development and a delay in Friend Virus-induced erythroleukemia Mol. Cell. Biol. 16, 2708-2718.

Morimoto, A. M., Jordan, K. C., Tietze, K., Britton, J. S., O’Neill, E. M. and Ruohola-Baker, H. (1996). Pointed, an ETS domain transcription factor, negatively regulates the EGF receptor pathway in Drosophila oogenesis. Development 122, 3745-3754.

Murakami, K., Mavrothalassitis, G., Bhat, N. K., Fisher, R. J. and Papas, T. S. (1993). Human ERG-2 protein in a phosphorylated DNA-binding protein - a distinct member of the ets family. Oncogene 8, 1559-1566.

Muthusamy, N., Barton, K. and Leiden, J. M. (1995). Defective activation and survival of $\mathrm{T}$ cells lacking the Ets-1 transcription factor. Nature $\mathbf{3 7 7}$, 639-642.

Nikolajczyk, B. S., Cortes, M., Feinman, R. and Sen, R. (1997) Combinatorial determinants of tissue-specific transcription in B cells and macrophages. Mol. Cell. Biol. 17, 3527-3535.

Olson, M. C., Scott, E. W., Hack, A. A., Su, G. H., Tenen, D. G., Singh, H. and Simon, M. C. (1995). PU.1 is not essential for early myeloid gene expression but is required for terminal myeloid differentiation. Immunity $\mathbf{3}$, 703-714.

Owen, M. J. and Venkitaraman, A. R. (1996). Signalling in lymphocyte development. Curr. Opin. Immunol. 8, 191-198.

Pénit, C., Lucas, B. and Vasseur, F. (1995). Cell expansion and growth arrest phases during the transition from precursor $\left(\mathrm{CD}^{-} 8^{-}\right)$to immature $\left(\mathrm{CD} 4^{+} 8^{+}\right)$ thymocytes in normal and genetically modified mice. J. Immunol. 154, 5103-5113.

Prasad, D. D. K., Rao, V. N., Lee, L. and Reddy, S. P. (1994). Differentially spliced $\operatorname{erg}-3$ product functions as a transcriptional activator. Oncogene $\mathbf{9}$, 669-673.

Ray-Gallet, D., Tavitian, A. and Moreau-Gachelin, F. (1996). An 
alternatively spliced isoform of the Spi-B transcription factor. Biochem. Biophys. Res. Commun. 223, 257-263.

Reya, T. and Grosschedl, R. (1998). Transcriptional regulation of B-cell differentiation. Curr. Opin. Immunol. 10, 158-165.

Rincon, M. and Flavell, R. A. (1996). Regulation of AP-1 and NFAT transcription factors during thymic selection of T cells. Mol. Cell. Biol. 16, 1074-1084.

Rivera, R. R., Stuiver, M. H., Steenbergen, R. and Murre, C. (1993). Ets proteins: new factors that regulate immunoglobulin heavy-chain gene expression. Mol. Cell. Biol. 13, 7163-7169.

Rolink, A., ten Boekel, E., Melchers, F., Fearon, D. T., Krop, I. and Andersson, J. (1996). A subpopulation of B220 ${ }^{+}$cells in murine bone marrow does not express CD19 and contains natural killer cell progenitors. J. Exp. Med. 183, 187-194.

Rothenberg, E. (1995). Developmental biology of lymphocytes. The Immunologist 3, 172-175.

Rothenberg, E. V. (1992). The development of functionally responsive T cells. Adv. Immunol. 51, 85-214.

Rothenberg, E. V., Chen, D. and Diamond, R. A. (1993). Functional and phenotypic analysis of thymocytes in SCID mice: evidence for functional response transitions before and after the SCID arrest point. J. Immunol. 151, 3530-3546.

Rothenberg, E. V., Diamond, R. A. and Chen, D. (1994). Programming for recognition and programming for response: separate developmental subroutines in the murine thymus. Thymus 22, 215-244.

Rothenberg, E. V., Telfer, J. C. and Anderson, M. K. (1999). Transcriptional regulation of lymphocyte lineage commitment. BioEssays (in press).

Scott, E. W., Fisher, R. C., Olson, M. C., Kehrli, E. W., Simon, M. C. and Singh, H. (1997). PU.1 functions in a cell-autonomous manner to control the differentiation of multipotential lymphoid-myeloid progenitors. Immunity 6, 437-447.

Scott, E. W., Simon, M. C., Anastasi, J. and Singh, H. (1994). Requirement of transcription factor PU.1 in the development of multiple hematopoietic lineages. Science 265, 1573-1577.

Shortman, K. and Wu, L. (1996). Early T lymphocyte progenitors. Annu. Rev. Immunol. 14, 29-47.

Simon, A. K., Auphan, N. and Schmitt-Verhulst, A. M. (1996).
Developmental control of antigen-induced thymic transcription factors. Int Immunol. 8, 1421-1428.

Su, G. H., Ip, H. S., Cobb, B. S., Lu, M.-M., Chen, H.-M. and Simon, M. C. (1996). The Ets protein Spi-B is expressed exclusively in B cells and T cells during development. J. Exp. Med. 184, 203-214.

Tan, P. B., Lackner, M. R. and Kim, S. K. (1998). MAP kinase signaling specificity mediated by the LIN-1 Ets/LIN-31 WH transcription factor complex during C. elegans vulval induction. Cell 93, 569-580.

Tenen, D. G., Hromas, R., Licht, J. D. and Zhang, D.-E. (1997). Transcription factors, normal myeloid development, and leukemia. Blood 90, 489-519.

Vanhecke, D., Verhasselt, B., Debacker, V., Leclercq, G., Plum, J. and Vandekerckhove, B. (1995). Differentiation to T-helper cells in the thymus - gradual acquisition of T-helper cell-function by CD3(+)CD4(+) cells. $J$. Immunol. 155, 4711-4718.

Voso, M. T., Burn, T. C., Wulf, G., Lim, B., Leone, G. and Tenen, D. G. (1994). Inhibition of hematopoiesis by competitive binding of transcription factor PU.1. Proc. Natl. Acad. Sci. USA 91, 7932-7936.

Wang, H., Diamond, R. A. and Rothenberg, E. V. (1998a). Cross-lineage expression of $\operatorname{Ig}-\beta$ (B29) in thymocytes: positive and negative gene regulation to establish T-cell identity. Proc. Natl. Acad. Sci. USA 95, 68316836.

Wang, H., Diamond, R. A., Yang-Snyder, J. A. and Rothenberg, E. V. (1998b). Precocious expression of T-cell functional response genes in vivo in primitive thymocytes before T-lineage commitment. Int. Immunol. 10, 1623-1635.

Wei, Z., Angerer, L. M., Gagnon, M. L. and Angerer, R. C. (1995). Characterization of the SpHE promoter that is spatially regulated along the animal-vegetal axis of the sea urchin embryo. Dev. Biol. 171, 195-211.

Wu, L., Li, C.-L. and Shortman, K. (1996). Thymic dendritic cell precursors: relationship to the $\mathrm{T}$ lymphocyte lineage and phenotype of the dendritic cell progeny. J. Exp. Med. 184, 903-911.

Zhang, Y. and Lichtenheld, M. G. (1997). Non-killer cell-specific transcription factors silence the perforin promoter. J. Immunol. 158, 17341741.

Zúñiga-Pflücker, J. C. and Lenardo, M. J. (1996). Regulation of thymocyte development from immature progenitors. Curr. Opin. Immunol. 8, 215-224. 